\title{
A Systematic Review of Mindfulness-Based School Interventions with Early Adolescents
}

\author{
Phillipa McKeering ${ }^{1}$ (D) Yoon-Suk Hwang $^{1}$
}

Published online: 18 July 2018

(C) The Author(s) 2018

\begin{abstract}
Recent research on mindfulness-based interventions (MBIs) in schools have reported effect differences across age groups of students, with early adolescent students reporting the least effect. Existing reviews, however, include students across all age ranges and largely concern intervention effects and their contributors. The exclusion of qualitative data exploring students' experiences of learning and practising mindfulness omits valuable information that could be used to better inform implementation of MBIs. The lack of quality critique employed in the existing reviews necessitates a new review. A search carried out in nine electronic databases resulted in an initial selection of 1571 records, from which 13 papers emerged that met all inclusion criteria. The review found positive improvements reported in well-being measures in 11 of the 13 papers examined across both quantitative and qualitative data that provide support for mindfulness as a well-being school preventative program with this age group. A quality analysis critique of each paper demonstrated methodological strengths and limitations of existing MBI studies for early adolescent students, which inform ongoing conversations about whether and how MBIs meet the criteria of evidence-based practice (EBP) as an effective educational program. Findings are discussed for future research and education considerations are reviewed for educational professionals who aim to support early adolescents through the implementation of MBIs at school.
\end{abstract}

Keywords Mindfulness $\cdot$ Well-being $\cdot$ School $\cdot$ Student $\cdot$ Adolescence $\cdot$ Youth

\section{Introduction}

Significant biological, neurodevelopmental, social and psychological changes occur during the early adolescence developmental stage, the period between 11 and 14 years of age (Patton et al. 2016). Important health and social problems either start or peak from early adolescence through to young adulthood (World Health Organisation [WHO] 2017a). Mental health in particular is a concern, with $20 \%$ of young people experiencing a mental health problem within any given year (WHO 2017b). The perceived stigma in accessing mental health services (Lawrence et al. 2015) and the shortage of mental-health professionals (Patel et al. 2007) are known to make it difficult for many young people with mental health issues to receive adequate support. Left untreated, mental health issues can have a significant and detrimental effect on

Phillipa McKeering

Phillipa.mckeering@myacu.edu.au

1 Learning Sciences Institute Australia, Australian Catholic University, Brisbane, Australia students' well-being, functioning and development (McGorry et al. 2014). It is therefore important that early intervention and prevention strategies are developed for this age group.

Schools are a universal access point to deliver services promoting health and well-being to early adolescents (WHO 2017b). School-based well-being programs also provide effective support for students in minimising mental health risk (Dray et al. 2014). Mindfulness-based interventions (MBIs) are one such school-based well-being program for promoting the health and well-being of school-aged students. While school-based MBIs differ in program content and outcomes measured, preliminary evidence supports their benefit for the well-being of students (Weare 2013). Reported benefits include an increase in positive affect measures, such as a person's sense of happiness and optimism post-intervention (Sampaio de Carvalho et al. 2017), as well as reductions in negative affect measures, such as feelings of being afraid or worried (Sibinga et al. 2016).

While MBIs have been delivered to students across diverse age groups, ranging from ages 5 to 19 years of age, only recently have studies suggested that MBIs may be more effective in some developmental stages than in others (e.g. 
Atkinson and Wade 2015). Carsley et al. (2017) conducted a meta-analysis which found that studies conducted in late adolescence (ages 15-18 years) ( $n=7$; Hedges' $\mathrm{g}=0.28,95 \%$ CI [ .17 , $.39], p<.001$ ) had higher pre-post effects on mental health and well-being outcomes compared to studies with middle childhood students (ages 6-10 years) ( $n=6$; Hedges' $\mathrm{g}=0.20,95 \%$ CI $[.03, .37])$. Their review also found no significant pre-post effects reported in mental health and well-being outcomes in early adolescent students (ages 11-14 years) ( $n=6$; Hedges' $\mathrm{g}=0.11, p=.213)$. Differences in the development of selfconcept and neurocognitive maturity may influence MBI effects. Differences in self-concept between preadolescent (grades 4-5) and early adolescent students (grades 6-7) may lead to differences in self-awareness (Schonert-Reichl and Lawlor 2010), a key element of mindfulness. Neurocognitive maturity may also influence the effects of MBIs across different age groups (Johnson et al. 2017). Given the developmental significance of early adolescence and the proven effectiveness of school-based well-being programs for minimising mental health risk, it is important to closely examine school-based MBI studies targeted for early adolescents.

There have been several systematic reviews on MBI effects with adolescents, but they included studies implementing MBIs in a broad range of settings (e.g. Klingbeil et al. 2017; Meiklejohn et al. 2012). To date, there have been three reviews conducted exclusively on MBIs within the school environment (i.e. Carsley et al. 2017; Felver et al. 2016; Zenner et al. 2014). In the review conducted by Zenner et al. (2014) significant positive effects were documented in the group design studies, such as improvements in cognitive performance and resilience. Similarly, the review by Felver et al. (2016) reported MBI intervention outcomes, including a reduction in behavioural problems, anxiety, depression, affective disturbances and suicidal ideation, and an increase in executive functioning. Carsley et al. (2017) review also reported small to moderate significant effects from pre-post MBI compared to control groups. Additionally, moderator analysis reported effects from: program facilitator (e.g. teacher or external facilitator) (Carsley et al. 2017), developmental period of student (Carsley et al. 2017) and intervention dosage (e.g. total minutes of mindfulness practice) (Zenner et al. 2014).

All the reviews, however, show methodological and empirical limitations. The diverse range of student ages included in the reviews (e.g. 5 to 19 years) makes it difficult to guide future implementation of MBIs with a specific age group of students or within a particular school environment (e.g. middle school). Given the reports of differences in age effect, a new review is needed to provide a collective account of all MBIs specifically with early adolescent school-aged students and to address some of the methodological and empirical limitations surrounding past MBI school reviews. In addition, Felver et al.'s (2016) review included all MBI studies delivered within a school setting, including those with a 'general population' of students, as well as programs specifically delivered to a cohort of students recruited because of behavioural difficulties (Singh et al. 2007), health problems (Lagor et al. 2013) or learning difficulties (Beauchemin et al. 2008). This diversity in student characteristics makes it difficult to determine whether effects reported are specific to a particular cohort of students or to a wider population, which is important given the different effect sizes reported across separate settings with youth (Klingbeil et al. 2017). The lack of quality critique employed by the authors to examine the rigour of each study also warrants a mention. A quality analysis critique can be used in evidence-based practice to inform judgements on the quality of a paper (Hwang et al. 2017). Empirical-based evidence is derived from direct and indirect observations that are provided by both quantitative and qualitative design experiments (Goodwin and Goodwin 2016). The exclusion of qualitative data in these reviews therefore omits valuable information that could be used to better inform implementation of MBIs.

This systematic review aims to provide a collective account of school-based MBIs conducted exclusively with early adolescent school-aged students while addressing the identified methodological and empirical limitations of current reviews on school-based MBIs. In doing so, the review is expected to provide practical and educational implications for practitioners working with early adolescent school-aged students in accordance with the concept of evidence-based practice (EBP). EBP in education is an approach adopted to ensure all aspects of education, from classroom practice to policy making, are based on significant and reliable evidence (Hempenstall 2006). EBP includes professional judgement, client values and best available evidence derived from significant and reliable studies, including qualitative and quantitative research (Slocum et al. 2012). Best evidence requires the most relevant evidence be examined to ensure the highest degree of certainty in decision making (Spencer et al. 2012). Within the field of education, the use of quality criteria can provide a consistent and explicit overview of a study design to guide EBP (Phillips et al. 2016). A source for evidence-based education includes the "What Works Clearinghouse" (Version 4.0) operated by the US Department of Education's Centre for Education Evaluation and Regional Assistance (NCEE), which evaluates educational programs by both evidence and effectiveness (What Works Clearinghouse [WWC] 2017). The standards developed by WWC can be used to inform educational professionals about the best available evidence as well as limitations in studies. Systematic reviews are instrumental in implementing EBP by providing a transparent research synthesis to education professionals to enable them to make informed judgements about educational programs (Hwang et al. 2017).

The review aims to advance the current understanding of school-based MBIs for early adolescents by addressing the identified methodological and empirical limitations of current 
reviews on school-based MBIs. Four research objectives were developed in conducting this review. Firstly, the review aims to examine the reported outcomes of mindfulness-based school programs with early adolescent school students (1114 years). As part of the review process, we will conduct a quality analysis critique of each reviewed study. Existing quality indicators will be applied to examine the methodological rigour of quantitative and qualitative studies under review and new quality indicators of mixed method studies will be developed and applied in their absence. The inclusion of qualitative data in the review will incorporate the experience of students who learn and practise mindfulness into the review outcomes and generate educational implications for teaching and researching mindfulness with this age group. Finally, the review aims to inform educators of the practical implications of implementing MBIs with early adolescent students in the future.

\section{Method}

\section{Search Strategy}

The search was conducted in October 2017 under the guidelines of Preferred Reporting Items for Systematic Review and Meta-Analysis Protocols (PRISMA-P) (Shamseer et al. 2015). A search was carried out in the following electronic databases: PsycINFO, ERIC, PsycARTICLES, Education Source, Scopus, Academic OneFile, Medline, PubMed, A+ Education. The following search terms were included: Mindful* OR Mindfulness*, AND school* OR classroom* OR lesson* OR education* AND student* OR youth* OR adolescent*. In addition to the electronic search, a review of all articles published in the Mindfulness Journal was undertaken, along with a hand search of the reference list of all relevant identified articles. The search strategy focused on the title, key words and abstract of each record. No date limitations were applied to ensure a comprehensive search. The first author performed the search under guidance and recommendations on the inclusion criteria that the second author provided. A total of 1571 articles were identified in the search. Duplicates were then removed $(n=590)$ and 981 records were screened to determine whether or not they meet the inclusion criteria (Fig. 1).

Prior to conducting the literature search, the inclusion criteria were developed and then applied to the search results. The inclusion criteria were: (a) peer-reviewed articles, (b) articles published in English, (c) participants were school students aged between 11 and 14 years, (d) intervention took place in a school setting, (e) mindfulness was the lead practice in the intervention, (f) the students reflected a 'general classroom' and $(\mathrm{g})$ had not been specifically recruited based on targeted emotional, learning, behavioural or intellectual difficulties. The 'peer reviewed' criteria were included to ensure that scientific rigour was upheld in the review and the restriction of 'English' language was added to ensure that the papers could be easily interpreted and understood by the researchers. The papers were screened to ensure that the program was implemented within the school environment and the age of students in the program was between 11 and 14 years of age (identified through the mean age of participants).

For inclusion in the study, the program needed to demonstrate that mindfulness was used as the main component of the intervention program (rather than studies that looked at mindfulness solely as a trait) and to identify that the program was mindfulness-based as opposed to a concentration-based program (e.g. Transcendental Meditation). Programs that incorporated other elements into the mindfulness-based program (e.g. yoga practice) were included, providing that the main component of the program was mindfulness-based. Intervention programs that incorporated mindfulness as one dimension of the program (e.g. Dialectical Behaviour therapy and Acceptance and Commitment therapy) were excluded from the review.

After screening records for the inclusion criteria, 667 records were excluded. The final 314 papers were thoroughly screened to ensure that they meet the inclusion criteria and 301 articles were removed at this time that did not meet: age criteria $(n=54)$, mindfulness was not the main component of the intervention $(n=147)$, student recruitment was on targeted health, intellectual, academic, behavioural or emotional characteristics $(n=97)$ and the intervention setting was not predominantly within the school day $(n=3)$. As a result, 13 articles adopting quantitative $(n=7)$ and mixed method $(n=6)$ design were included in this review. Of these, nine studies have been published since 2014 and the first study was published in 2004. These studies reported the effects of MBIs with early adolescent students attending schools in the USA $(n=6)$, Australia $(n=4)$, New Zealand $(n=1)$, Canada $(n=1)$ and the UK $(n=1)$.

\section{Quality Analysis Critique}

A methodological quality critique was performed on the 13 papers included in this review, using quality indicators developed for quantitative and qualitative studies by authors (Hwang et al. 2017). In the absence of quality indicators for mixed-method studies, new indicators were developed based on the work of Heyvaert et al. (2013), Pluye et al. (2009) and Hwang et al. (2017). The inclusion of the mixed-method design studies in this review is important given the considerable amount of criticism over methodologies employed in mindfulness research to date (Shankland and Rosset 2017; Tan 2016). Quantitative studies have been criticised as being too restrictive in seeking a specific hypothesis, and in so doing possibly missing other outcomes of an intervention (Bernay et 
Fig. 1 PRISMA diagram

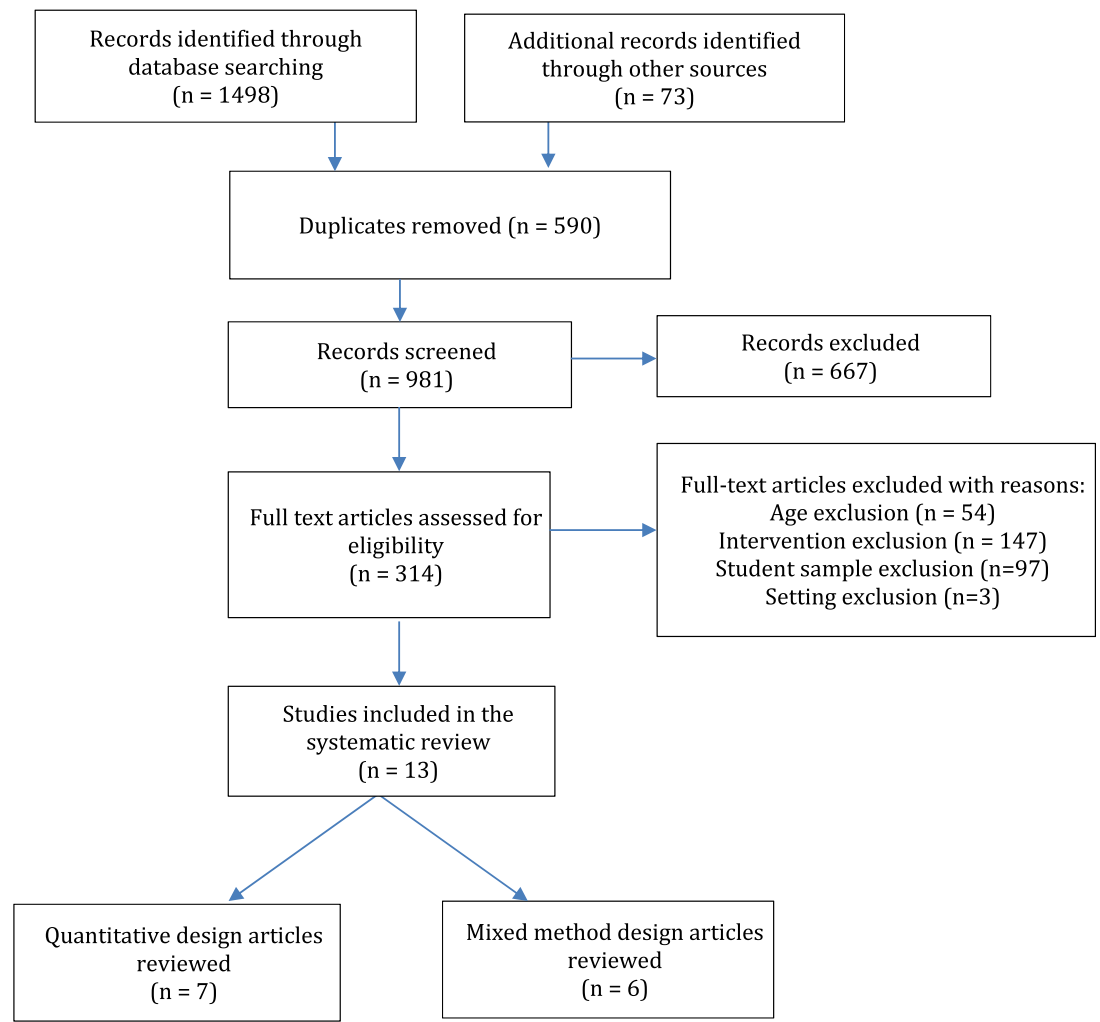

al. 2016). Similarly, qualitative studies have been criticised for the small sample sizes and subjectivity reported in the results (Burke 2010).

The two authors independently reviewed each paper against the identified quality analysis indices, using 17 quantitative design indicators, 21 mixed-method (quantitative focus) design indicators and 19 mixed-method design (qualitative focus) design indicators. The results produced an initial agreement on 224 and disagreement on 17 of 241 quality indicators. Further discussions yielded agreement on the 17 indicators that were under dispute. The six mixed-method papers were examined to identify their weighting towards qualitative or quantitative focus to ensure that quality indicators were employed relevant to the study design. The researchers identified four of the papers as having a stronger quantitative focus and two papers as having a stronger qualitative focus. The appraisal was used to indicate to the reader the quality and relevance of each paper and not to discard any of the papers. The results of the 13 papers are presented in Tables 1, 2 and 3 according to the research design of each paper with the quality indicators for each paper referenced as a footnote under each table.

\section{Analysis}

The findings of the seven quantitative studies and the quantitative findings of the four mixed-method (quantitative focus) studies were extracted to examine research methods and intervention effects of the MBI for the health and well-being of early adolescent students. The qualitative findings of the six mixed-method studies (both qualitative and quantitative foci) were extracted and inserted into Nvivo 11, a qualitative data analysis software program, for secondary analysis. Analysis began with (1) reading the extracted primary qualitative findings, (2) generating and reviewing initial codes to elucidate students' experience of learning mindfulness and teachers' experience of implementing a MBI, (3) searching for overarching themes that allow consistent patterns to emerge and (4) clustering the initial codes according to their relationships with the identified overarching themes (Braun and Clarke 2006).

\section{Results}

This review analysed 13 studies of MBIs with early adolescent school students. The review outcomes are presented under the following three categories, research method, mindfulness intervention and practice and experience. The number of quality appraisal indicators met by the seven quantitative studies ranged from 11 (Sibinga et al. 2016) to 15 (Barnes et al. 2004; Johnson et al. 2017) on a total of 17 measures (Table 1). The quality appraisal indicators met by the four mixed-method (quantitative focus) studies ranged from 12 (Viafora et al. 2015) to 17 (Britton et al. 2014) on a total of 
Table 1 Quantitative studies included in the review

\begin{tabular}{|c|c|c|c|c|c|}
\hline Study & Design & Participants & Objective & Program, content and duration & Methods \\
\hline $\begin{array}{l}\text { Barnes, Davis, } \\
\text { Murzynowski, } \\
\text { \& Treiber } \\
\text { (2004) }\end{array}$ & $\begin{array}{l}\text { Pre-post randomised design } \\
\text { with active control group } \\
\text { The control group undertook } \\
\text { health education }\end{array}$ & $\begin{array}{l}73 \text { middle-school students from } \\
4 \text { science classes at a public } \\
\text { school } \\
(\mathrm{M}=12.3 \text { years, } \mathrm{SD}=0.6 \\
\quad 47 \% \text { females) } \\
\text { (Intervention group } N=34 ; \\
\quad \text { health education control } \\
\quad \text { group } N=39 \text { ) }\end{array}$ & $\begin{array}{l}\text { To evaluate the effects of a } \\
\text { mindfulness program on } \\
\text { resting and ambulatory } \\
\text { blood pressure and heart } \\
\text { rate }\end{array}$ & $\begin{array}{l}\text { Breath meditation exercise } \\
10 \text { min sessions conducted at } \\
\text { school and at home each } \\
\text { day for } 3 \text { months }\end{array}$ & $\begin{array}{l}\text { Experiential exercise on breath } \\
\text { awareness each day } \\
\text { A weekly } 20 \text {-min group } \\
\text { discussion on feelings, } \\
\text { and body sensations } \\
\text { experienced during the } \\
\text { practice and benefits of } \\
\text { the practice }\end{array}$ \\
\hline $\begin{array}{l}\text { Johnson, Burke, } \\
\text { Brinkman, \& } \\
\text { Wade (2016) }\end{array}$ & $\begin{array}{l}\text { Pre-, post-, and 3-month } \\
\text { follow-up randomised } \\
\text { control design with control } \\
\text { group } \\
\text { The control group undertook } \\
\text { normal curricular lessons } \\
\text { (pastoral care and } \\
\text { community projects) }\end{array}$ & $\begin{array}{l}308 \text { students from years } 7 \text { (one } \\
\text { public primary school) and } \\
\text { years } 8 \text { (three public and } \\
\text { one private high school) } \\
\text { from urban coeducational } \\
\text { schools } \\
(\mathrm{M}=13.63 \text { years, } \mathrm{SD}=0.43 ; \\
48 \% \text { females) } \\
\text { (Intervention group } N=132 ; \\
\text { control group } N=176)\end{array}$ & $\begin{array}{l}\text { To assess whether a MBI could } \\
\text { be replicated in an } \\
\text { Australian school context } \\
\text { independent of program } \\
\text { developers and to examine } \\
\text { its effect on anxiety, } \\
\text { depression and eating } \\
\text { disorder in early adolescent } \\
\text { students } \\
\text { To examine whether any } \\
\text { benefits were moderated by } \\
\text { increased home practice }\end{array}$ & $\begin{array}{l}\text { MiSP's .b manualised program } \\
\text { Lessons included both formal } \\
\text { and informal practices in } \\
\text { breath awareness, body } \\
\text { sensations, thoughts, and } \\
\text { feelings } \\
\text { Modified to } 8 \text { weekly lessons } \\
\text { ( } 35-60 \text { min each) plus } \\
\text { optional homework }\end{array}$ & $\begin{array}{l}\text { Didactic, interactive and } \\
\text { experiential instruction } \\
\text { Instructor led class discussion } \\
\text { and use of a course manual } \\
\text { Optional e-format homework } \\
\text { and audiofiles for exercises }\end{array}$ \\
\hline $\begin{array}{l}\text { Johnson, Burke, } \\
\text { Brinkman, \& } \\
\text { Wade (2017) }\end{array}$ & $\begin{array}{l}\text { Pre-, post- and follow-up } \\
\text { randomised control design } \\
\text { with } 2 \text { different intervention } \\
\text { groups (with and without } \\
\text { parent involvement) and a } \\
\text { control group } \\
\text { The control group undertook } \\
\text { normal curricular lessons } \\
\text { (pastoral care, community } \\
\text { projects etc.) }\end{array}$ & $\begin{array}{l}555 \text { students from four urban } \\
\text { coeducational secondary } \\
\text { schools (one private, three } \\
\text { public) } \\
(\mathrm{M}=13.44 \text { years, } \mathrm{SD}=0.33 ; \\
45 \% \text { females) } \\
\text { (Intervention group with parent } \\
\text { involvement } N=191 ; \\
\text { intervention group without } \\
\text { parent involvement } \\
N=186 \text {; control group } \\
N=178 \text { ) }\end{array}$ & $\begin{array}{l}\text { To evaluate a tighter replication } \\
\text { of a mindfulness program } \\
\text { To identify whether parent } \\
\text { involvement in the program } \\
\text { increases home practice } \\
\text { compliance and } \\
\text { intervention effects }\end{array}$ & $\begin{array}{l}\text { MiSP's .b manualised program } \\
\text { Lessons included formal and } \\
\text { informal practices in breath } \\
\text { awareness, body sensations, } \\
\text { thoughts, and feelings } \\
\text { The standard curriculum was } \\
\text { strengthened by; emphasing } \\
\text { motivation in practicing, } \\
\text { starting each lesson with a. } \\
\text { b practice, A3 posters of } \\
\text { practices displayed in } \\
\text { classrooms, laminated } \\
\text { handouts of practices and } \\
\text { key ideas } \\
9 \text { weekly lessons ( } 40-60 \text { min } \\
\text { each) plus optional } \\
\text { homework }\end{array}$ & $\begin{array}{l}\text { Didactic and experiential } \\
\text { instruction } \\
\text { Instructor led class discussion } \\
\text { Weekly quiz to refresh on prior } \\
\text { themes } \\
\text { Optional homework sheets and } \\
\text { audiofiles for exercises }\end{array}$ \\
\hline $\begin{array}{l}\text { Quach, Jastrowski, } \\
\text { \& Alexander } \\
\text { (2016) }\end{array}$ & $\begin{array}{l}\text { Pre-post randomised control } \\
\text { design with } 2 \text { different } \\
\text { intervention groups and a } \\
\text { waitlist control group }\end{array}$ & $\begin{array}{l}198 \text { students aged between } 12 \\
\text { and } 15 \text { years from a large } \\
\text { junior high school } \\
\text { predominantly from } \\
\text { low-income households } \\
(\mathrm{M}=13.18 \text { years, } \mathrm{SD}=0.72 ; \\
62 \% \text { females) } \\
\text { (Mindfulness intervention } \\
\text { group } N=61 \text {; Hatha yoga } \\
\text { intervention group } N=68 ; \\
\text { waitlist control group } \\
N=57 \text { ) }\end{array}$ & $\begin{array}{l}\text { To evaluate the effects of a } \\
\text { mindfulness school } \\
\text { program on working } \\
\text { memory capacity (WMC) } \\
\text { in adolescents compared to } \\
\text { a Hatha yoga intervention } \\
\text { and control group } \\
\text { To examine the effect of both } \\
\text { interventions on perceived } \\
\text { stress and anxiety }\end{array}$ & $\begin{array}{l}\text { Mindfulness based stress } \\
\text { reduction (MBSR) } \\
\text { Each lesson consisted of } \\
\text { breathing techniques, } \\
\text { formal meditation and } \\
\text { discussion } \\
\text { Both intervention programs } \\
\text { delivered twice a week } \\
\text { (45 min) for } 4 \text { weeks }\end{array}$ & $\begin{array}{l}\text { Formal meditation practice } \\
\text { Instructor led class discussion } \\
\text { Audio recording of practices } \\
\text { and encouraged to practice } \\
\text { daily for } 15-30 \text { min and } \\
\text { record home practice in a } \\
\log \end{array}$ \\
\hline $\begin{array}{l}\text { Schonert-Reichl } \\
\text { and Lawlor } \\
\text { (2010) }\end{array}$ & $\begin{array}{l}\text { Pre-post non-randomised quasi } \\
\text { experimental design with a } \\
\text { waitlist control group }\end{array}$ & $\begin{array}{l}246 \text { students from } 4 \text { th to } 7 \text { th } \\
\text { grade in } 12 \text { elementary } \\
\text { urban schools aged } \\
\text { 9-13 years } \\
\text { (Intervention } N=139 ; \\
\quad \mathrm{M}=11.1 \text { years, } \mathrm{SD}=1.18 \text {; } \\
49 \% \text { females, waitlist } \\
\text { control } N=107 ; \\
\mathrm{M}=11.65 \text { years, } \\
\mathrm{SD}=0.83 ; 47 \% \text { females) }\end{array}$ & $\begin{array}{l}\text { To examine the effects of a } \\
\text { mindfulness-based program } \\
\text { on optimism, self-concept, } \\
\text { positive affect, and } \\
\text { social-emotional } \\
\text { functioning in pre- and } \\
\text { early- adolescent students }\end{array}$ & $\begin{array}{l}\text { Mindfulness Education (ME) } \\
\text { Lessons included mindful } \\
\text { attention, breathing, } \\
\text { emotion regulation and } \\
\text { loving kindness } \\
40-50 \text { min sessions once a } \\
\text { week + daily core } \\
\text { mindfulness exercises } 3 \\
\text { times a day for } 3 \text { mins each } \\
\text { for } 9-10 \text { weeks }\end{array}$ & $\begin{array}{l}\text { Verbal instruction (with a } \\
\text { curriculum manual } \\
\text { including detailed script) } \\
\text { Materials for teaching } \\
\text { mindfulness skills }\end{array}$ \\
\hline $\begin{array}{l}\text { Sibinga et al. } \\
\text { (2013) }\end{array}$ & $\begin{array}{l}\text { Pre-, post-, and 3-month } \\
\text { follow-up randomised } \\
\text { controlled design with } \\
\text { active control group } \\
\text { The control group undertook } \\
\text { heath education }\end{array}$ & $\begin{array}{l}41 \text { male students from } 7 \text { th and } \\
\text { 8th grade at a small school } \\
\text { for low-income urban boys } \\
(\mathrm{M}=12.5 \text { years; } 100 \% \text { males }) \\
\text { (Mindfulness intervention } \\
\text { group } N=22 ; \text { Health } \\
\text { education group } N=19)\end{array}$ & $\begin{array}{l}\text { To determine whether a } \\
\text { mindfulness-based school } \\
\text { intervention is associated } \\
\text { with reduced psychological } \\
\text { symptoms and enhanced } \\
\text { coping in urban male } \\
\text { adolescents }\end{array}$ & $\begin{array}{l}\text { Adaption of } M B S R \text { program } \\
12 \text { weekly sessions ( } 50 \mathrm{~min})\end{array}$ & No information provided \\
\hline $\begin{array}{l}\text { Sibinga, Webb, } \\
\text { Ghazarian, \& } \\
\text { Ellen (2016) }\end{array}$ & $\begin{array}{l}\text { Pre-post randomised trial with } \\
\text { active control group } \\
\text { The control group undertook } \\
\text { heath education }\end{array}$ & $\begin{array}{l}300 \text { students from } 5 \text { th to } 8 \text { th } \\
\text { grade from } 2 \text { public schools } \\
\text { (M=12.0 years; } 51 \% \\
\text { females) } \\
\text { (Intervention } N=159 ; \text { active } \\
\text { control of a health } \\
\text { education program } \\
N=141 \text { ) }\end{array}$ & $\begin{array}{l}\text { To examine the effects of a } \\
\text { mindfulness-based } \\
\text { intervention on the negative } \\
\text { effects of stress and trauma } \\
\text { in low-income, minority } \\
\text { students in middle school }\end{array}$ & $\begin{array}{l}\text { Adaption of } M B S R \text { program } \\
\text { Lessons included: Didactic } \\
\text { material (meditation, yoga, } \\
\text { mind-body connection); } \\
\text { experiential practice (formal } \\
\text { and informal); and home } \\
\text { practice options } \\
\text { 12-week program (session } \\
\text { duration and frequency } \\
\text { unspecified) }\end{array}$ & $\begin{array}{l}\text { Didactic and experiential } \\
\text { instruction, and group } \\
\text { discussion to apply } \\
\text { mindfulness to everyday } \\
\text { situations }\end{array}$ \\
\hline
\end{tabular}


Table 1 (continued)

\begin{tabular}{|c|c|c|c|c|c|}
\hline Study & Instructors & Measures & Type of measure & Quality analysis & Results \\
\hline $\begin{array}{l}\text { Barnes, Davis, } \\
\text { Murzynowski, } \\
\text { \& Treiber } \\
\text { (2004) }\end{array}$ & $\begin{array}{l}\text { One science teacher for both } \\
\text { intervention and active } \\
\text { control groups } \\
\text { (Details on training or } \\
\text { experience not reported) }\end{array}$ & $\begin{array}{l}\text { Resting systolic blood } \\
\text { pressure (SBP) } \\
\text { Diastolic blood } \\
\quad \text { pressure (DBP) } \\
\text { Heart rate (HR) } \\
\text { Height and Weight } \\
\text { Spielberger Anger } \\
\text { expression scale and } \\
\text { Neighbourhood } \\
\text { stress index } \\
\text { Self-report on physical } \\
\text { activity }\end{array}$ & $\begin{array}{l}\text { Physical measures } \\
\text { Student self-report }\end{array}$ & $\begin{array}{r}1,2,3,4,5,6,8,9,10 \\
11,12,13,14,16,17\end{array}$ & $\begin{array}{l}\text { Between group comparison: } \\
\text { Only the mindfulness group } \\
\text { showed significant } \\
\text { decreases in (1) resting } \\
\text { SBP and (2) daytime after } \\
\text { school ambulatory SBP, } \\
\text { DBP, and HR }\end{array}$ \\
\hline $\begin{array}{r}\text { Johnson, Burke, } \\
\text { Brinkman, \& } \\
\text { Wade (2016) }\end{array}$ & $\begin{array}{l}\text { External facilitator } \\
\text { (10 years of personal practice, } \\
\text { completed adult facilitator } \\
\text { training, and delivered the } \\
\text { program once before with } \\
\text { a small pilot community } \\
\text { adolescent group) }\end{array}$ & $\begin{array}{l}\text { Depression Anxiety } \\
\text { Stress (DASS-21) } \\
\text { Eating Disorder } \\
\text { examination - } \\
\text { questionnaire (EDE-Q) } \\
\text { Warwick-Edinburgh } \\
\text { Mental well-being } \\
\text { (WEMWBS) } \\
\text { Child and adolescent } \\
\text { mindfulness (CAMM) } \\
\text { Difficulties in Emotional } \\
\text { regulation (DERS) } \\
\text { Self-compassion (SCS) } \\
\text { Acceptability and home } \\
\text { practice questionnaire }\end{array}$ & Student self-report & $\begin{array}{c}1,2,3,4,5,6,8,9,11 \\
12,13,14,15,16\end{array}$ & $\begin{array}{l}\text { Between group comparison: } \\
\text { No improvements in all outcome } \\
\text { variables at post and follow-up } \\
\text { time intervals for the } \\
\text { intervention group compared } \\
\text { to the control group } \\
\text { (Cohen's } d=\text { from } .01 \text { to } \\
.28, p>.05 \text { ) } \\
\text { Anxiety was higher in } \\
\text { intervention group for } \\
\text { males at follow-up } \\
\text { (Cohen's } d=.22, p<.05 \text { ) } \\
\text { Intervention group: } \\
\text { High acceptability of the } \\
\text { program and facilitator } \\
\text { (mean score of } 7 \text { out of } 10) \\
\text { Low rates of home practice } \\
\text { uptake }(26 \%)\end{array}$ \\
\hline $\begin{array}{r}\text { Johnson, Burke, } \\
\text { Brinkman, \& } \\
\text { Wade (2017) }\end{array}$ & $\begin{array}{l}\text { External facilitator } \\
\text { (10 years of personal practice, } \\
\text { trained in different mindfulness } \\
\text { programs, prior delivery of } \\
\text { the program } 8 \text { times) }\end{array}$ & $\begin{array}{l}\text { Negative affect: Depression } \\
\text { Anxiety stress scale } \\
\text { (DASS-21) } \\
\text { Weight and shape concern: } \\
\text { Eating Disorder examination } \\
\text { (EDE-Q) } \\
\text { Well-being: Warwick-Edinburgh } \\
\text { Mental well-being (WEMWBS) } \\
\text { Mindfulness: comprehensive } \\
\text { inventory of mindfulness } \\
\text { experiences - adolescents } \\
\text { (CHIME-A) }\end{array}$ & Student self-report & $\begin{array}{r}1,2,3,4,5,6,7,8,9 \\
11,12,13,14,15,16\end{array}$ & $\begin{array}{l}\text { Between group comparison: } \\
\text { No differences in outcomes } \\
\text { between any of the groups } \\
\text { at post, } 6 \text {-month or } 12 \text {-month } \\
\text { follow-up (Cohen's } d=\text { from } \\
.002 \text { to } .37, p<.05 \text { ) }\end{array}$ \\
\hline $\begin{array}{l}\text { Quach, Jastrowski, } \\
\text { \& Alexander } \\
\text { (2016) }\end{array}$ & $\begin{array}{l}\text { Mindfulness intervention: } \\
\text { delivered by } 2 \text { external } \\
\text { facilitators who had completed } \\
\text { mindfulness training programs } \\
\text { with } 5-10 \text { years of meditation } \\
\text { experience } \\
\text { Hatha yoga intervention: delivered } \\
\text { by } 2 \text { instructors with } 200 \text {-h yoga } \\
\text { teacher training certification } \\
\text { with } 6-10 \text { years of yoga } \\
\text { teaching experience }\end{array}$ & $\begin{array}{l}\text { Automated Operation Span } \\
\text { Task (AOSPAN) } \\
\text { Perceived Stress Scale } 10 \\
\text { (PSS-10) } \\
\text { Screen for Child Anxiety } \\
\text { and Related Emotional } \\
\text { Disorders (SCARED) } \\
\text { Child Acceptance and } \\
\text { Mindfulness measure } \\
\text { (CAMM) }\end{array}$ & $\begin{array}{l}\text { Student self-report } \\
\text { and cognitive } \\
\text { assessment }\end{array}$ & $\begin{array}{l}1,2,3,4,5,6,7,8 \\
\quad 9,11,12,13,14,15\end{array}$ & $\begin{array}{l}\text { Between group comparison: } \\
\text { The mindfulness intervention } \\
\text { group reported a significant } \\
\text { improvement in working } \\
\text { memory capacity (AOSPAN, } \\
\text { partial } \eta^{2}=.24, p<.001 \text { ) } \\
\text { compared to the hatha yoga } \\
\text { (partial } \eta^{2}=.04, p=.11 \text { ) } \\
\text { and control groups (partial } \\
\eta^{2}=.01, p<.46 \text { ) } \\
\text { No significant between-group } \\
\text { differences found for stress } \\
\text { and anxiety }\end{array}$ \\
\hline $\begin{array}{l}\text { Schonert-Reichl } \\
\text { and Lawlor } \\
\text { (2010) }\end{array}$ & $\begin{array}{l}12 \text { Teachers (6 in waitlist } \\
\text { control) } \\
\text { Teacher training included } \\
1 \text { day session plus twice } \\
\text { weekly consultation with } \\
\text { one of the authors of } \\
\text { the } M E \text { program }\end{array}$ & $\begin{array}{l}\text { Optimism scale from Resilience } \\
\text { Inventory (RI) } \\
\text { Positive and negative affect } \\
\text { schedule (PANAS) } \\
\text { School self-concept and general } \\
\text { self-concept subscales from } \\
\text { the Self-Description } \\
\text { Questionnaire (SD) } \\
\text { Teacher rating scale of social } \\
\text { and emotional competence } \\
\text { (TRSC) }\end{array}$ & $\begin{array}{l}\text { Student self-report } \\
\text { Teacher report on student }\end{array}$ & $\begin{array}{r}1,3,4,5,6,7,8,9 \\
12,13,14,15,17\end{array}$ & $\begin{array}{l}\text { Between group comparison: } \\
\text { Increase in self-reported optimism } \\
\text { (partial } \eta^{2}=.018, p<.05 \text { ) } \\
\text { and positive affect (partial } \\
\eta^{2}=.009, p<.10 \text { ) for the } \\
\text { intervention group compared } \\
\text { to the control group } \\
\text { An increase in self-reported } \\
\text { general self-concept for } \\
\text { pre-adolescents only (partial } \\
\eta^{2}=.014, p<.05 \text { ) } \\
\text { Increase in teacher report of } \\
\text { attention (partial } \eta^{2}=.120, \\
p<.001 \text { ), emotional regulation } \\
\text { (partial } \eta^{2}=.041, p<.001 \text { ) } \\
\text { and social and emotional } \\
\text { competence (partial } \eta^{2}=.260, \\
p<.001 \text { ) for the intervention } \\
\text { group } \\
\text { Reduction in teacher report of } \\
\text { aggression (partial } \eta^{2}=.074, \\
p<.001 \text { ) } \\
\text { Between group comparison: }\end{array}$ \\
\hline
\end{tabular}


Table 1 (continued)

\begin{tabular}{|c|c|c|c|c|c|}
\hline $\begin{array}{l}\text { Sibinga et al. } \\
\text { (2013) }\end{array}$ & $\begin{array}{l}\text { Delivered by an external } \\
\text { facilitator trained at the } \\
\text { University of Massachusetts } \\
\text { centre for mindfulness } \\
\text { with over } 10 \text { years' } \\
\text { experience in mindfulness } \\
\text { instruction for young people }\end{array}$ & $\begin{array}{l}\text { Psychological functioning } \\
\quad \text { (SCL-90-R) } \\
\text { Coping (COPE) } \\
\text { Mindfulness (CAMM) } \\
\text { Sleep measures: sleep diary, } \\
\text { Respironics, mini mitter } \\
\quad \text { actiwatch, wrist actigraph } \\
\text { Salivary cortisol }\end{array}$ & $\begin{array}{l}\text { Physiological } \\
\text { assessments }\end{array}$ & $\begin{array}{l}1,2,3,4,8,9,11 \\
12,13,14,15,16,17\end{array}$ & $\begin{array}{l}\text { The mindfulness group reported } \\
\text { less anxiety (Cohen's } d=.79, \\
p=.01 \text { ), less rumination } \\
\text { (Cohen's } d=.64, p=.02 \text { ) } \\
\text { and improved negative coping } \\
\text { (Cohen's } d=.87, p=.06 \text { ), } \\
\text { compared to the active } \\
\text { control group }\end{array}$ \\
\hline $\begin{array}{l}\text { Sibinga, Webb, } \\
\text { Ghazarian, \& } \\
\text { Ellen (2016) }\end{array}$ & $\begin{array}{l}\text { Instructors were recruited } \\
\text { from community partner } \\
\text { organisation } \\
\text { No information provided on } \\
\text { the training they underwent } \\
\text { or how many people were } \\
\text { involved } \\
\text { Data collected by program staff }\end{array}$ & $\begin{array}{l}\text { Mindfulness: } \\
\text { CAMM } \\
\text { Psychological symptoms: } \\
\text { (CDI-S; } \\
\text { SCL-90-R; } \\
\text { MASC) } \\
\text { Mood and emotion regulation: } \\
\text { (PANAS; } \\
\text { DES; } \\
\text { STAXI-2) } \\
\text { Coping: } \\
\text { (CRSQ; } \\
\text { Brief COPE; } \\
\text { CSE) } \\
\text { Posttraumatic symptoms: } \\
\text { (CPSS) }\end{array}$ & Student self-report & $\begin{array}{c}1,2,3,4,8,9,11 \\
12,13,14,17\end{array}$ & $\begin{array}{l}\text { Between group comparison: } \\
\text { Post program the intervention } \\
\text { group reported lower levels } \\
\text { on: } \\
\text { Somatisation }(\beta=-.13, p=.03), \\
\quad \text { depression }(\beta=-.16, p=.02), \\
\text { negative coping }(\beta=-.13, \\
p=.003), \text { negative affect } \\
(\beta=-.13, \mathrm{p}=.03), \text { rumination } \\
(\beta=-.13, p=.04) \text {, self-hostility } \\
(\beta=-.14, p=.02), \text { and } \\
\text { posttraumatic stress symptoms } \\
(\beta=-.15, p=.02), \text { compared } \\
\text { to the active control group }\end{array}$ \\
\hline
\end{tabular}

Quality indicators of quantitative study: (1) aims \& objectives, (2) random assignment of participants, (3) sufficient information about participants, (4) similarity between groups at the start of the intervention, (5) sufficient information about intervention, (6) information about comparison conditions, (7) fidelity of intervention, (8) balance between measures of intervention and performance, (9) reliability of outcome measures, (10) validity of outcome measures, (11) information about attrition, (12) ethical consideration, (13) alignment between research questions and data analysis, (14) clear presentation of results, (15) effect size reported, (16) measurement of intervention effect at the appropriate times, (17) cost-benefit analysis

21 measures (Table 2), and those by the two mixed-method (qualitative focus) studies were 6 (Arthurson 2015) to 15 (Costello and Lawler 2014) on a total of 19 measures (Table 3). Such variation indicates that some studies had stronger methodological rigour than others.

\section{Research Method}

\section{Design and Method}

Of the 11 papers with a quantitative focus, including the four mixed-method design papers, seven adopted a pre-post randomised controlled trial with control group to examine the effects of a MBI with early adolescent school students. Four of these papers (Barnes et al. 2004; Britton et al. 2014; Sibinga et al. 2013, 2016) employed an active control (e.g. health education class), two papers (Johnson et al. 2016, 2017) used a control group (e.g. usual curricular) and one study had a waitlist control group (Quach et al. 2016). Three of these studies also examined the sustainability of the intervention effects, reporting 3-month follow-up (Johnson et al. 2016; Sibinga et al. 2013), and 6- and 12-month follow-up (Johnson et al. 2017) effects.

Of the remaining four non-randomised studies, two were pre-post design with a waitlist control group (Schonert-Reichl and Lawlor 2010; Viafora et al. 2015) and two were pre-post without control group (Bernay et al. 2016; Joyce et al. 2010). Information on comparison conditions in the quantitative papers with active control, control or waitlist control groups were reported in seven of the nine papers (Barnes et al. 2004; Britton et al. 2014; Johnson et al. 2016, 2017; Quach et al. 2016; Schonert-Reichl and Lawlor 2010; Viafora et al. 2015), including details on program format, structure, duration and facilitator. Attrition information was reported in seven of the studies (Barnes et al. 2004; Britton et al. 2014; Johnson et al. 2016, 2017; Quach et al. 2016; Sibinga et al. 2013, 2016), and ethical considerations were documented in all the review papers except one (Arthurson 2015).

\section{Reliability, Validity, Trustworthiness, Credibility and Fidelity of Intervention}

While reliability measures were recorded on all of the 11 papers with quantitative studies, validity of outcome measures was reported in only three of the papers (Barnes et al. 2004; Bernay et al. 2016; Britton et al. 2014). Convergent validity was reported on self-report measures in all three studies, with construct validity reported in only one study (Bernay et al. 2016). In the two mixed-method (qualitative) design studies, neither provided documentation on the trustworthiness and credibility of the study (e.g. member checking, inter-coder agreement) nor provided a reflexivity statement.

The fidelity of the intervention was only reported in three of the papers under review (Johnson et al. 2017; Quach et al. 2016; Schonert-Reichl and Lawlor 2010). Johnson et al. (2017) developed a fidelity and competence check in their delivery of the intervention across three domains: (1) coverage, pacing and organisation; (2) embodiment of mindfulness; and (3) guiding of mindfulness practices. Assessment 
Table 2 Mixed-method studies included in the review (quantitative focus)

\begin{tabular}{|c|c|c|c|c|c|}
\hline Study & Design & Participants & Objective & Program, content and duration & Methods \\
\hline $\begin{array}{l}\text { Bernay, Graham, } \\
\text { Devcich, Rix, \& } \\
\text { Rubie-Davis } \\
\text { (2016) }\end{array}$ & $\begin{array}{l}\text { Pre-, post-, and 3-month } \\
\text { follow-up mixed- } \\
\text { method } \\
\text { design without control } \\
\text { group }\end{array}$ & $\begin{array}{l}124 \text { elementary school } \\
\text { children from } 3 \text { New } \\
\text { Zealand schools aged } \\
9-12 \text { years }(\mathrm{M}=11.14 \\
\mathrm{SD}=1.18 ; 51 \% \text { females })\end{array}$ & $\begin{array}{l}\text { To examine the effects of a } \\
\text { mindfulness-based } \\
\text { intervention on student } \\
\text { well-being } \\
\text { To understand their } \\
\text { perception of the program }\end{array}$ & $\begin{array}{l}\text { Pause, Breath, Smile program } \\
\text { (developed by the Mental Health } \\
\text { Foundation of New Zealand to } \\
\text { reflect attitudes of health and } \\
\text { well-being held by the indigenous } \\
\text { population) } \\
\text { Specific lessons covered themes of } \\
\text { breath-body awareness, sensory } \\
\text { awareness, practices for promoting } \\
\text { kindness and gratitude, } \\
\text { emotion-regulation, and } \\
\text { interconnectedness } \\
8 \times 1 \text { h weekly intervention }\end{array}$ & $\begin{array}{l}\text { Verbal instruction } \\
\text { Experiential exercises } \\
\text { Guided meditation } \\
\quad \text { CD (for teachers to } \\
\text { use) }\end{array}$ \\
\hline $\begin{array}{l}\text { Britton } \\
\quad \text { et al. (2014) }\end{array}$ & $\begin{array}{l}\text { Pre - post randomised } \\
\text { control trial with active } \\
\text { control group } \\
\text { (Intervention = Asian } \\
\text { history class with } \\
\text { mindfulness; Active } \\
\text { control = African } \\
\text { history class + } \\
\text { experiential activity) }\end{array}$ & $\begin{array}{l}101 \text { sixth grade students } \\
\text { from two consecutive } \\
\text { years in an independent } \\
\text { Quaker school } \\
(\mathrm{M}=11.79 \text { years, } \\
\mathrm{SD}=0.41 \text {; females } 46 \%)\end{array}$ & $\begin{array}{l}\text { To examine the effects of a } \\
\text { non-elective } \\
\text { mindfulness-based } \\
\text { intervention on mental } \\
\text { health and affect in } \\
\text { middle school children }\end{array}$ & $\begin{array}{l}\text { Roth's Integrative Contemplative } \\
\text { Pedagogy (ICP) } \\
\text { Lessons covered 'third person' didactic, } \\
\text { knowledge based learning with 'first } \\
\text { person' experiential learning } \\
\text { Lessons included: Breath awareness, } \\
\text { breath counting, awareness of } \\
\text { thoughts and feelings, body } \\
\text { sensations, and body sweeps } \\
3-12 \text { min sessions } 5 \text { times a week } \\
\text { for } 6 \text { weeks delivered at the start } \\
\text { of each history lesson }\end{array}$ & $\begin{array}{l}\text { Verbal instruction and } \\
\text { guided practice } \\
\text { within history } \\
\text { lessons }\end{array}$ \\
\hline $\begin{array}{l}\text { Joyce, Etty-Leal, } \\
\text { Zazryn, Hamilton, } \\
\text { \& Hassed (2010) }\end{array}$ & $\begin{array}{l}\text { Pre-post mixed-method } \\
\text { design without control } \\
\text { group }\end{array}$ & $\begin{array}{l}175 \text { children from } 2 \text { primary } \\
\text { schools in Melbourne } \\
\text { from Grades } 5 \text { and } 6 \text { aged } \\
\text { between } 10 \text { and } 13 \text { years } \\
(\mathrm{M}=11.3 \text { years; } 44 \% \\
\text { females })\end{array}$ & $\begin{array}{l}\text { To examine the effect of a } \\
\text { mindfulness-based } \\
\text { program on mental health } \\
\text { measures in students aged } \\
10-13 \text { years }\end{array}$ & $\begin{array}{l}\text { Based on MBSR } \\
\text { (not prescriptive) and developed by } \\
\text { the } 2 \text { nd author } \\
\text { Lessons included: self-awareness, } \\
\text { paying attention, body and breath } \\
\text { awareness } \\
10 \times 45 \text { min sessions plus optional daily } \\
\text { exercises (teachers were encouraged } \\
\text { to deliver the program that suited } \\
\text { their class \& timetable) }\end{array}$ & $\begin{array}{l}\text { Teacher tailored } \\
\text { self-awareness and } \\
\text { relaxation } \\
\text { exercises } \\
\text { Group discussion } \\
\text { combined with } \\
\text { formal practice }\end{array}$ \\
\hline $\begin{array}{l}\text { Viafora, Mathiesen \& } \\
\text { Unsworth (2015) }\end{array}$ & $\begin{array}{l}\text { Pre-post } \\
\text { quasi-experimental } \\
\text { design with two } \\
\text { treatment groups and a } \\
\text { non-equivalent } \\
\text { comparison group }\end{array}$ & $\begin{array}{l}63 \text { students from Grade } 6 \text { to } \\
8 \text { (aged } 11-13 \text { years) } \\
\text { from } 4 \text { middle school } \\
\text { classrooms at } 2 \text { schools } \\
\text { ( } 52 \% \text { females) } \\
\text { (Intervention grp } N=28 ; \\
\text { waitlist non- equivalent } \\
\text { group } N=20 ; \text { school with } \\
\text { students facing } \\
\text { homelessness } N=15 \text { ) }\end{array}$ & $\begin{array}{l}\text { To examine whether an } \\
\text { 8-week mindfulness } \\
\text { course would foster } \\
\text { protective coping factors } \\
\text { in adolescents attending a } \\
\text { traditional school or a } \\
\text { school with students } \\
\text { at-risk of homelessness } \\
\text { To evaluate the acceptability } \\
\text { and feasibility of the } \\
\text { course }\end{array}$ & $\begin{array}{l}\text { Adaption of Planting Seeds and Still } \\
\text { Quiet Place } \\
\text { Lessons included: mindful breathing } \\
\text { and awareness, sensory awareness } \\
\text { and mindful movement } \\
45 \text { mins weekly for } 8 \text { weeks }\end{array}$ & $\begin{array}{l}\text { Didactic and } \\
\text { experiential } \\
\text { instruction } \\
\text { Instructor led class } \\
\text { discussion, role } \\
\text { play activities, and } \\
\text { home activity } \\
\text { practice }\end{array}$ \\
\hline
\end{tabular}

\begin{tabular}{|c|c|c|c|}
\hline Study & Instructors & Measures & Type of measure \\
\hline $\begin{array}{l}\text { Bernay, Graham, } \\
\text { Devcich, Rix, \& } \\
\text { Rubie-Davis } \\
\text { (2016) }\end{array}$ & $\begin{array}{l}3 \text { experienced facilitators } \\
\text { trained by a research } \\
\text { team member }\end{array}$ & $\begin{array}{l}\text { Mindful Awareness Attention } \\
\text { Scale for children } \\
\text { (MAAS-C) } \\
\text { Stirling Children's Well-being } \\
\text { scale (SCWBS) } \\
\text { Teacher observation of student } \\
\text { behaviour } \\
\text { Student interview }\end{array}$ & $\begin{array}{l}\text { Student self-report } \\
\text { measure } \\
\text { Teacher observations } \\
\text { recorded in } \\
\text { journals } \\
\text { Student interviews } \\
\quad(N=6)\end{array}$ \\
\hline
\end{tabular}

Quality analysis Results

$1,3,5,8,9,10, \quad$ Within group comparison:

$12,13,14,15, \quad$ No increase in mindfulness between baseline $17,18,19,20, \quad$ and post intervention but an increase at 21 3 -month follow up (partial $\eta^{2}=.05$, $p=.005)$

Significant increase in student well-being post intervention but returned to baseline at 3-month follow-up (partial $\eta^{2}=.04$, $p=.008$ ). Changes to mindfulness were positively related to changes in well-being $(r=.38, p<.001)$

Student interviews: Active engagement and acceptability of the program, and positive social-emotional benefits

Teacher observations: Improvement in student behaviour and classroom climate
Britton

et al. (2014)
2 instructors were history

teachers - one with 5

years meditation

experience, and the

other having completed

the 8 week MBSR course
Youth Self Report (YSF)

Modified Spielberger

State-Trait Anxiety

(STAI-C) inventory - child version
Student self-report

Student journal entry
$1,2,3,4,5,6,8$,

$9,10,11,12$

$13,14,15,17$,

18,19
Between and within group comparison:

A reduction in suicidal ideation (likelihood ratio $=7.73, p=.005$ ) and affective disturbance (Cohen's $d=.41, p=.05$ ) found only in the mindfulness group 
Table 2 (continued)

$\begin{array}{lc}\begin{array}{l}\text { Both instructors } \\ \text { followed the same } \\ \text { instruction transcripts }\end{array} & \text { Cognitive and Affective } \\ & \text { mindfulness measure } \\ & \text { (CAMS-R) } \\ & \text { Student journal entries }\end{array}$

Student journal entries

No significant changes in mindfulness among any groups over time (Cohen's $d=.00, p=.78)$

Both groups showed improvements on internalising problems, externalising problems, attention problem subscales and affect measures but no difference in magnitude between groups

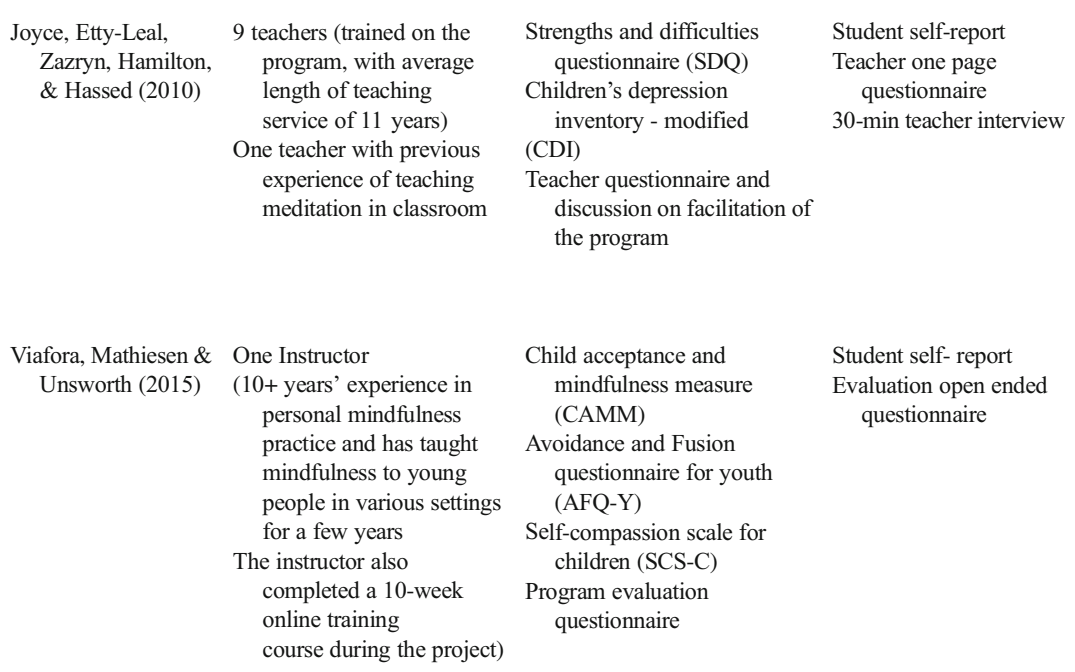

Student self-report

Teacher one page questionnaire

Child acceptance and mindfulness measure (CAMM)

Avoidance and Fusion questionnaire for youth (AFQ-Y)

Self-compassion scale for children (SCS-C)

Program evaluation questionnaire

Student self- report Evaluation open ended questionnaire

, 3, 5, 9, 12, 13, 14, Within group comparison:

$15,16,17,18, \quad$ Significant decrease in Total Difficulties

19, 20, 21. Score of SDQ (Cohen's $d=.38, p<.00$ ) and CDI (Cohen's $d=.27, p<.01$ ) for all students

Significant improvement in Pro-social scale of SDQ (Cohen's $d=.21, p<.05$ ) for students identified in the 'borderline' or 'abnormal' category

Positive teacher feedback on their experience with the program

$1,5,6,8,9,12,13$, No significant interaction between time and $17,18,19,20,21$ group found for the AFQ-Y and SCS-C Only students in traditional classrooms reported increased mindfulness from preto post-intervention $(\mathrm{p}<.01)$

Students facing homelessness reported higher evaluations of the course and its generalisability for use in the future

Quality indicators of mixed method (predominantly quantitative study): (1) aims and objectives, (2) random assignment of participants, (3) sufficient information about participants, (4) similarity between groups at the start of the intervention, (5) sufficient information about intervention, (6) information about comparison conditions, (7) fidelity of intervention, (8) balance between measures of intervention and performance, (9) reliability of outcome measures, (10) validity of outcome measures, (11) information about attrition, (12) ethical consideration, (13) alignment between research questions and data analysis, (14) clear presentation of results, (15) effect size reported, (16) measurement of intervention effect at the appropriate times, (17) costbenefit analysis, (18) rationale for MM design stated, (19) integration of quantitative and qualitative components outlined, (20) qualitative design and analysis appropriate and credible, (21) interpretation/findings support the MM design

occurred after each mindfulness lesson. In the study by Quach et al. (2016), intervention fidelity was applied through the use of a mindfulness curriculum manual and schedule for the facilitator to follow. The researcher also attended ad hoc sessions to ensure minimal variability in the delivery of the intervention. Schonert-Reichl and Lawlor (2010) sought feedback from teachers delivering the program on their perspective of how effectively they delivered the program and what improvements could be made to future delivery (e.g. "I could have used more time to review and implement the program").

\section{Mindfulness Intervention}

\section{Participants}

Student sample sizes were reported in all 13 papers in the review with a total number of 2277 early adolescent participants. The seven quantitative papers had a total of 1721 participating students, ranging from 41 (Sibinga et al. 2013) to 555 students (Johnson et al. 2017). The six mixed-method papers had a total of 556 participating students, ranging from 30 (Arthurson 2015) to 175 students (Joyce et al. 2010). The gender of students was reported in all studies except one (Arthurson 2015). Of the studies that reported gender, all had a mix of both male and female students, except one study that only had male students (Sibinga et al. 2013). In the 12 studies where gender was reported, $49 \%$ of students were females.

All of the studies provided information on student's age. Two of the papers reported age range between 11 and 12 years (Arthurson 2015; Costello and Lawler 2014), one study reported age range between 11 and 13 years (Viafora et al. 2015) and the remaining ten studies reported a mean age between 11 and 14 years, with a minimum mean age of 11.1 years (Schonert-Reichl and Lawlor 2010) and a maximum mean age of 13.63 years (Johnson et al. 2016). Students attended either upper primary school, middle school or lower high schools. Of the 13 studies, two were conducted with private schools (Arthurson 2015; Britton et al. 2014), six with public schools (Barnes et al. 2004; Costello and Lawler 2014; Schonert-Reichl and Lawlor 2010; Sibinga et al. 2013, 2016; Viafora et al. 2015), two had students from both public and private schools (Johnson et al. 2016, 2017) and three did not provide this information (Bernay et al. 2016; Joyce et al. 2010; Quach et al. 2016). 


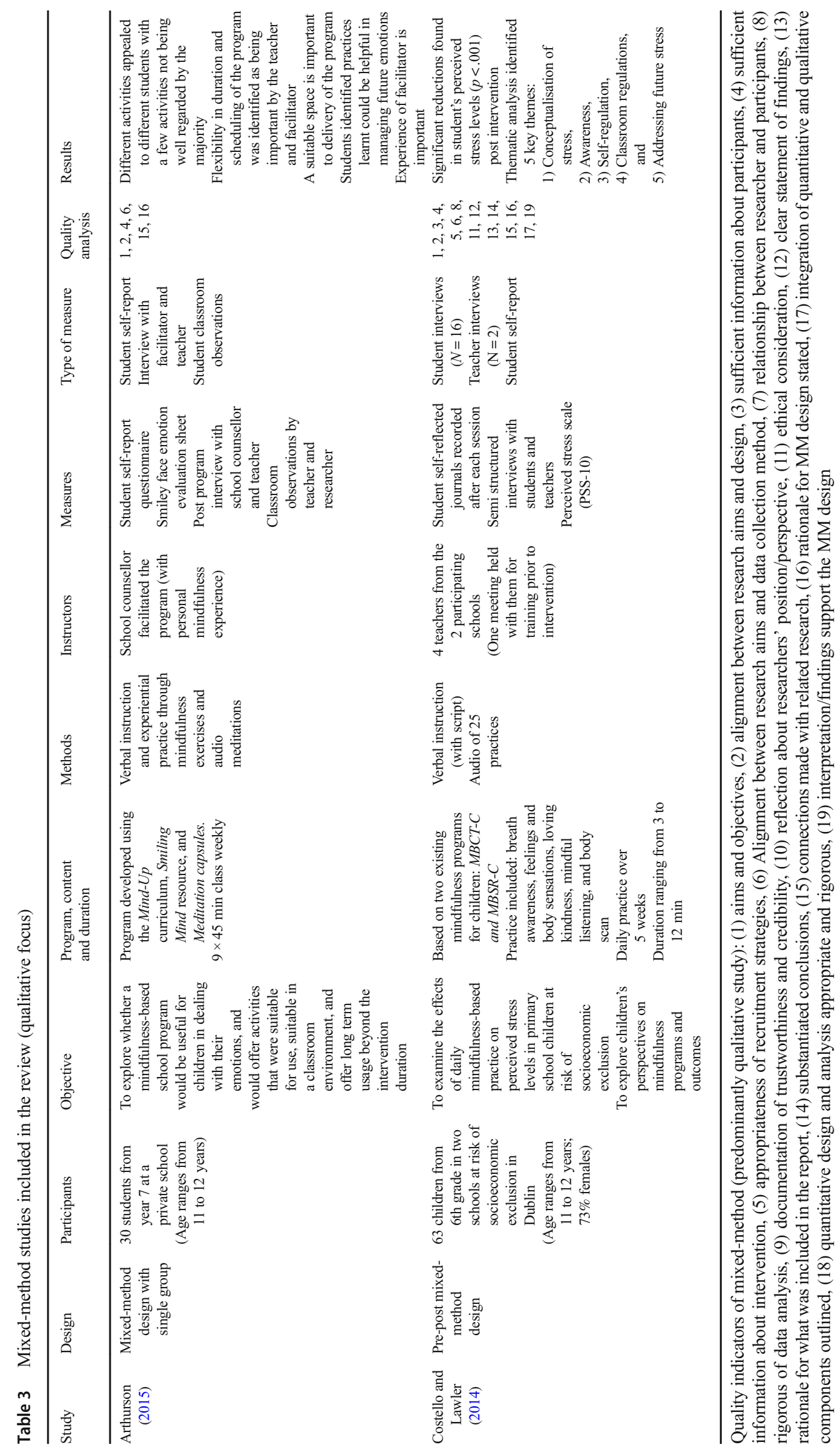




\section{Objectives}

All 13 of the papers under review examined the effect of a MBI for the well-being of early adolescent school-aged students. Twelve of the 13 papers examined well-being through student self-report measures as either an increase in positive mental health traits for the student (e.g. optimism, coping, self-compassion, self-concept and emotion regulation) (Arthurson 2015; Bernay et al. 2016; Schonert-Reichl and Lawlor 2010; Sibinga et al. 2013; Viafora et al. 2015), or as a reduction in negative mental health traits (e.g. anxiety, depression and stress) (Britton et al. 2014; Costello and Lawler 2014; Johnson et al. 2016, 2017; Joyce et al. 2010; Quach et al. 2016; Sibinga et al. 2013, 2016). One paper (Barnes et al. 2004) aimed to evaluate the effect of a MBI on physiological measures (e.g. blood pressure, heart rate).

In addition to the well-being-related outcomes, the effects of a MBI on cognitive functioning (Quach et al. 2016) were evaluated, along with intervention effects of home practice (Johnson et al. 2016) and parental involvement (Johnson et al. 2017). Finally, six of the studies aimed to better understand the acceptability and feasibility of implementing the program at school from students' and/or teachers' perspectives (Arthurson 2015; Bernay et al. 2016; Britton et al. 2014; Costello and Lawler 2014; Joyce et al. 2010; Viafora et al. 2015).

\section{Facilitators}

The facilitators who deliver the program are part of MBI interventions and their importance cannot be overemphasised (Hwang et al. 2017). It is believed that extensive and ongoing practice in mindfulness is required by the facilitator in order to best support the delivery of a MBI (Segal et al. 2002). In the 13 papers reviewed, 12 of the papers identified the facilitator of the program as either a teacher at the school $(n=6)$ (Arthurson 2015; Barnes et al. 2004; Britton et al. 2014; Costello and Lawler 2014; Joyce et al. 2010; SchonertReichl and Lawlor 2010) or an external facilitator $(n=6)$ (Bernay et al. 2016; Johnson et al. 2016, 2017; Quach et al. 2016; Sibinga et al. 2013; Viafora et al. 2015). Three of the studies provided no information on the training or experience of the instructor (Barnes et al. 2004; Bernay et al. 2016; Sibinga et al. 2016), with many others providing very little detail.

Of the 13 studies reviewed, five reported the instructor had a long-standing personal mindfulness practice (Britton et al. 2014; Johnson et al. 2016, 2017; Quach et al. 2016; Sibinga et al. 2013) and indicated the instructor had undertaken mindfulness training above that of a 1-day session (Johnson et al. 2016, 2017; Quach et al. 2016; Sibinga et al. 2013; Viafora et al. 2015). In addition to this, seven studies reported that the intervention was delivered by more than one instructor in their study (Bernay et al. 2016; Britton et al. 2014; Costello and Lawler 2014; Joyce et al. 2010; Quach et al. 2016; SchonertReichl and Lawlor 2010; Sibinga et al. 2016), which makes it difficult to ensure consistency and fidelity of the intervention program. Of these seven studies taught by multiple instructors, only two (Quach et al. 2016; Schonert-Reichl and Lawlor 2010) reported fidelity of the intervention program.

Two of the studies reviewed were delivered by the same facilitator (Johnson et al. 2016, 2017). This external facilitator was reported as having 10 years of personal practice with mindfulness, along with training in mindfulness programs and prior experience in delivery to this age group of students. This description indicates that the facilitator in the two studies was more experienced than facilitators in most of the other studies included in this review. This is worth noting as both of these studies did not find any positive intervention effects.

\section{Intervention Content and Duration}

In examining the intervention details, 11 of the 13 studies in the review provided detailed information on the intervention (Arthurson 2015; Barnes et al. 2004; Bernay et al. 2016; Britton et al. 2014; Costello and Lawler 2014; Johnson et al. 2016, 2017; Joyce et al. 2010; Quach et al. 2016; SchonertReichl and Lawlor 2010; Viafora et al. 2015). However, the format, structure and duration of the program delivered in each of these papers varied widely. Whilst a general consensus on a definition of mindfulness has not been reached, it has been operationalised as "paying attention on purpose, in the present moment, and non-judgementally to the unfolding of experience moment by moment" (Kabat-Zinn 2003, p.145). These programs are taught around a combination of practices, including formal activities (e.g. body scan meditation, sitting meditation) and informal activities (e.g. mindful eating, walking or listening), and generally include a component of both didactic and experiential learning.

Six papers stated that the program was adapted from the Mindfulness-Based Stress Reduction (MBSR) program (Barnes et al. 2004; Costello and Lawler 2014; Joyce et al. 2010; Quach et al. 2016; Sibinga et al. 2013, 2016), and two studies stated that they delivered the Mindfulness in Schools Project (MiSP) program (Johnson et al. 2016, 2017). The experiential exercise of breath awareness was identified in ten of the studies (Barnes et al. 2004; Bernay et al. 2016; Britton et al. 2014; Costello and Lawler 2014; Johnson et al. 2016, 2017; Joyce et al. 2010; Quach et al. 2016; Schonert-Reichl and Lawlor 2010; Viafora et al. 2015), with loving-kindness identified as a theme in two of the papers (Bernay et al. 2016; Schonert-Reichl and Lawlor 2010). Whilst all the studies provided both experiential and didactic learning, seven of the papers highlighted the component of instructor-led discussion in the program (Barnes et al. 2004; Johnson et al. 2016, 2017; Joyce et al. 2010; Quach et al. 2016; Sibinga et al. 2016; 
Viafora et al. 2015). A curriculum manual was documented in four of the papers to guide the instructor (Costello and Lawler 2014; Johnson et al. 2016, 2017; Schonert-Reichl and Lawlor 2010). One paper reported a descriptive rather than a prescriptive approach was used to deliver the program (Joyce et al. 2010), which can challenge the fidelity of intervention and replicability of the study if a novice facilitator delivers the intervention and no plan is in place to ensure intervention fidelity.

The duration of the program delivered ranged from short daily sessions to longer weekly sessions. The shortest daily program was reported to be between 3 and 12 min (Britton et al. 2014; Costello and Lawler 2014), and the longest weekly program was $1 \mathrm{~h}$ in duration (Bernay et al. 2016). The number of weeks the program was offered ranged from 4 (Quach et al. 2016) to 12 weeks (Sibinga et al. 2013). The shortest dosage of mindfulness was reported in programs that offered short daily lessons, which totalled between 187 (Costello and Lawler 2014) and $225 \mathrm{~min}$ (Britton et al. 2014) for the duration of the program. The longest dosage was reported in a program combining a weekly longer lesson with short practices three times a day for 9 weeks, totalling 810 min of mindfulness (Schonert-Reichl and Lawlor 2010). The longest single weekly lessons reported a range of between $380 \mathrm{~min}$ (Johnson et al. 2016) and $600 \mathrm{~min}$ (Barnes et al. 2004; Sibinga et al. 2013).

Home practice was an optional exercise offered in seven of the studies (Barnes et al. 2004; Johnson et al. 2016, 2017; Joyce et al. 2010; Quach et al. 2016; Sibinga et al. 2016; Viafora et al. 2015) and is worth noting as mindfulness homework has been shown to be an important element of mindfulness training (Semple et al. 2006). In addition to this, one of the studies invited parental involvement in the program by offering a 1-h information session on the intervention, followed by 10-min YouTube clips on lesson material weekly (Johnson et al. 2017). The findings from this study found no significant effect on parental involvement, but it is worth noting that parental involvement was extremely low. Parental post course feedback was $8 \%$ and the parents who viewed the YouTube clip had also reduced to $9 \%$ at the end of the course. Similarly, teacher uptake on the program in this study was also low.

\section{Intervention Measures and Effects}

Different measures were used in each of the studies to determine MBI effect and 11 out of the 13 studies reported positive effects on different well-being variables (Arthurson 2015; Barnes et al. 2004; Bernay et al. 2016; Britton et al. 2014; Costello and Lawler 2014; Joyce et al. 2010; Quach et al. 2016; Schonert-Reichl and Lawlor 2010; Sibinga et al. 2013, 2016; Viafora et al. 2015). Of the seven quantitative papers in the review, three relied exclusively on student self- report measures (Johnson et al. 2016, 2017; Sibinga et al. 2016), which can be an issue considering the social desirability bias that can arise when relying solely on self-report measures in examining the effects of an intervention (Creswell 2015). Of the remaining four quantitative design studies, in addition to self-report measures, physical measures (e.g. heart rate, sleeping patterns, salivary cortisol) (Barnes et al. 2004; Sibinga et al. 2013), cognitive assessment (Quach et al. 2016) and teacher-rated report (Schonert-Reichl and Lawlor 2010) were employed. All six of the mixed-method design studies used self-report measures. In addition to this, qualitative data were gathered from both students and teachers. Student experiences were recorded through the use of student journals or open-ended questionnaires (Joyce et al. 2010; Viafora et al. 2015), student classroom observations (Arthurson 2015) or through student interviews (Bernay et al. 2016; Costello and Lawler 2014). Teachers' experiences with implementing MBIs were recorded through observations and journals (Bernay et al. 2016; Joyce et al. 2010) and interviews (Arthurson 2015; Costello and Lawler 2014; Joyce et al. 2010).

Of the 11 quantitative design studies reviewed, nine studies (Barnes et al. 2004; Bernay et al. 2016; Britton et al. 2014; Joyce et al. 2010; Quach et al. 2016; Schonert-Reichl and Lawlor 2010; Sibinga et al. 2013, 2016; Viafora et al. 2015) reported positive improvements on physiological, cognitive and emotional well-being from pre- to post-test measures. These positive improvements were reported on blood pressure and heart rate (Barnes et al. 2004), working memory capacity (Quach et al. 2016, partial $\eta^{2}=.24, p<.001$ ) and an increase in mindfulness (Viafora et al. 2015). Positive improvements were also reported in self-reported emotional well-being measures that examined an increase in positive mental health traits and/or a reduction in negative mental health traits. An increase in positive mental health traits was reported on optimism and positive affect (Schonert-Reichl and Lawlor 2010, partial $\eta^{2}=.018, p<.05$ and partial $\eta^{2}=.009, p<.10$, respectively), improved well-being (Bernay et al. 2016, partial $\eta^{2}=.04$, $p=.008$ ) and prosocial functioning (Joyce et al. 2010, Cohen's $d=.21, p<.05$ ).

A reduction in negative mental health traits were reported in outcome variables including suicidal ideation and affective disturbances (Britton et al. 2014, likelihood ratio $=7.73$, $p=.005$ and Cohen's $d=.41, p=.05$, respectively), depression (Joyce et al. 2010, Cohen's $d=.27, p<.01$; Sibinga et al. 2016), negative coping (Sibinga et al. 2013, Cohen's $d=.87, p=.06$ ), negative affect, self-hostility, rumination (Sibinga et al. 2016) and anxiety (Sibinga et al. 2013, Cohen's $d=.79, p=.01$ ). One study also reported an increase in mindfulness in the intervention group at 3-month follow-up (Bernay et al. 2016, partial $\eta^{2}=.05, p=.005$ ). Teacher-rated measures reported positive improvements from pre- to posttest measures in Schonert-Reichl and Lawlor's (2010) study 
on student behaviour (partial $\eta^{2}=.074, p<.001$ ), attention (partial $\eta^{2}=.120, p<.001$ ), emotional regulation (partial $\left.\eta^{2}=.041, p<.001\right)$ and social and emotional competence (partial $\left.\eta^{2}=.260, p<.001\right)$. Positive improvements were also reported on post-test teacher-rated measures on classroom climate (Bernay et al. 2016).

Effect sizes were reported in eight of the 11 quantitative papers (Bernay et al. 2016; Britton et al. 2014; Johnson et al. 2016, 2017; Joyce et al. 2010; Quach et al. 2016; SchonertReichl and Lawlor 2010; Sibinga et al. 2013). They together formed an overall pattern as decreases in negative mental traits (e.g. affective disturbances, anxiety) were often reported with medium to large effect sizes while small effect sizes were reported for increases in positive mental traits (e.g. positive affect, prosocial functioning), except for working memory capacity (Quach et al. 2016, partial $\eta^{2}=.24, p<.001$ ). Two studies reported no positive improvement in the MBI (Johnson et al. 2016, 2017) at all time intervals across the primary outcome variables, including depression, anxiety and mindful awareness.

\section{Practice and Experience}

Secondary analysis of the qualitative findings of six mixedmethod studies generated two major themes: students' experiences of practising mindfulness and teachers' experiences of implementing mindfulness programs. Students' experiences of practising mindfulness consisted of student response, practice experience and perceived benefits (Fig. 2), while teachers' experience of implementing mindfulness consisted of student response, enablers of and barriers to successful implementation and perceived benefits for students (Fig. 3).

\section{Students' Experiences of Practising Mindfulness}

\section{Student Response}

When mindfulness was introduced in class, overall responses from students were positive and active. All (Bernay et al. 2016) or the majority of students (Arthurson 2015; Costello and Lawler 2014; Viafora et al. 2015) were engaged with the practice. It was perceived to be "fun" (Costello and Lawler 2014) and "helpful" (Arthurson 2015; Viafora et al. 2015). Some students, however, found it boring (Britton et al. 2014) and difficult to practise because of invasive thoughts, mind wandering and recurring thoughts (Costello and Lawler 2014). Sitting still also provoked a feeling of sadness and fatigue (Arthurson 2015). A minority of students disliked the practice (Arthurson 2015; Britton et al. 2014) and rejected it by means of daydreaming and classroom disruption (Britton et al. 2014).

\section{Practice Experience}

Students engaged with practice by slowing down and taking time to notice what is here and now (Bernay et al. 2016). Mindful breathing was used most frequently to anchor their mind to the present, and this had calming effects (Arthurson 2015; Bernay et al. 2016; Costello and Lawler 2014; Viafora et al. 2015). Slow eating allowed the experience of longlasting flavour (Bernay et al. 2016) and discovery of a new relationship with food (Arthurson 2015). Students applied what they learned and practised during the sessions at home, school and playgrounds to deal with family-related stress and difficult social interactions (Bernay et al. 2016; Costello and Lawler 2014; Viafora et al. 2015). Students became aware of when their minds wandered and learned to bring it back (Arthurson 2015; Costello and Lawler 2014). Awareness grew as they noticed mental and physical events they previously had not, such as bodily movements associated with breathing and precursory signs of panicking (Bernay et al. 2016; Costello and Lawler 2014). For some students, mindfulness practice helped them to pay attention to the feelings of others, which gave rise to kind actions such as sharing lunch with a student who was alone (Bernay et al. 2016).

\section{Perceived Benefits}

Practice engagement appears to be closely associated with seeing change. The pattern is that engaging with practice leads to seeing positive change in physical, mental and relational experiences, which contributes to further engagement with practice. Such change consisted of perceived benefits that manifested in a wide range of ways. Students mentioned psychological benefits most frequently, as they used meditation practices for their coping strategies (Arthurson 2015; Bernay et al. 2016; Costello and Lawler 2014; Viafora et al. 2015). Breathing meditation, for example, helped them feel calm and relaxed, which reduced stress, worry and anxiety, and increased concentration (Arthurson 2015; Bernay et al. 2016; Britton et al. 2014; Costello and Lawler 2014; Viafora et al. 2015). It also improved sleep quality (Arthurson 2015).

Emotion and behaviour regulation naturally occurred as students became aware of signs of anger and stress, felt the weakening of anger and stress by focusing on breathing and therefore stopped these signs from feeding into acting out (Bernay et al. 2016; Costello and Lawler 2014; Viafora et al. 2015). Behaviour regulation helped students make friends (Bernay et al. 2016) and improved their classroom behaviour (Costello and Lawler 2014). Management of psychological stress and test anxiety (Bernay et al. 2016; Costello and Lawler 2014), reductions of disruptive behaviours in class (Costello and Lawler 2014; Viafora et al. 2015) and enhancement of concentration (Bernay et al. 2016; Britton et al. 2014; 
Fig. 2 Students' experiences of practising mindfulness

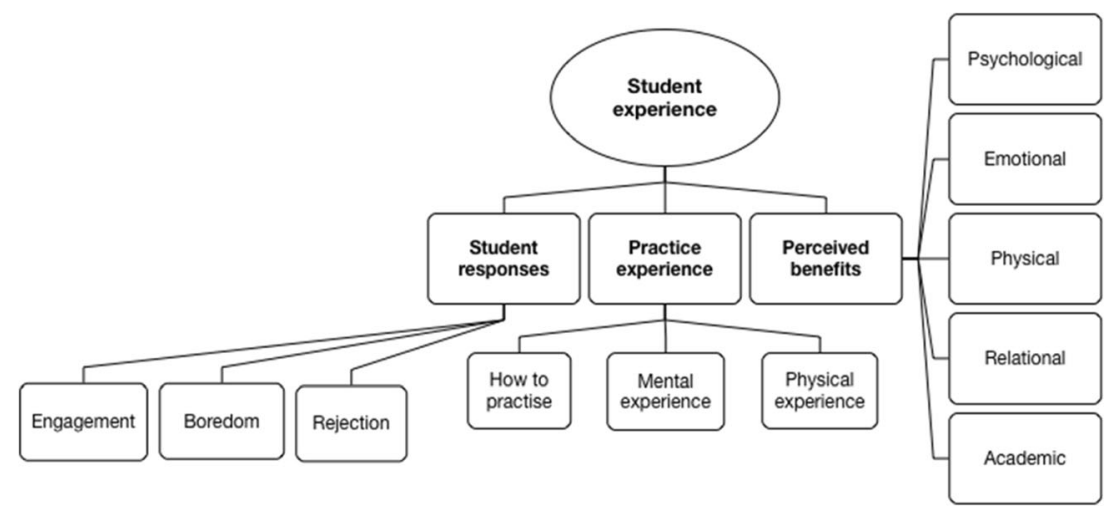

Costello and Lawler 2014; Viafora et al. 2015) together contributed to student academic learning.

\section{Teachers' Experiences of Implementing Mindfulness Programs}

\section{Student Response}

Arthurson (2015) and Joyce et al. (2010) reported teachers' experiences of delivering mindfulness activities in their class. Generally, teachers were positive about teaching mindfulness and found the majority of their students engaged with the activities they taught (Joyce et al. 2010). Different activities appealed to students differently, with students finding at least one activity enjoyable to practise (Arthurson 2015). However, some students had difficulty in taking the activities seriously and participating in the lessons (Joyce et al. 2010).

\section{Enablers of and Barriers to Successful Implementation}

Teachers identified a range of enablers that together created environments conducive to the successful implementation of classroom-based mindfulness intervention. They are teachers' ability to embody mindfulness, collaboration with fellow teachers, support from school administrators and parents, relaxing physical environment and students' willingness to learn (Joyce et al. 2010). Teachers nominated time pressure and crowded curriculum content as the biggest barrier, along with students' disengagement with the program (Joyce et al. 2010).

\section{Perceived Benefits for Students}

Teachers found their students made psychological, behavioural and learning progress over time from practising mindfulness activities (Arthurson 2015; Costello and Lawler 2014). The most commented-on change was students being relaxed and settled after meditation practices, which reduced disruptive behaviour and increased on-task behaviour as they became less reactive (Costello and Lawler 2014; Joyce et al. 2010).

\section{Discussion}

This systematic review aimed to provide a collective account of school-based MBIs conducted exclusively with early adolescent school-aged students (11-14 years) to develop practical and educational implications for educators working in accordance with the framework of EBP. In doing so, the paper conducted an extensive review of both quantitative and qualitative research to better understand the reported intervention effects, along with the acceptability and feasibility of the program by including students' and teachers' voices. The review conducted a quality analysis critique on all papers reviewed to examine the strengths and limitations that currently exist in research in this field, which will be useful for advancing research design and methodologies on school-based MBIs. The
Fig. 3 Teachers' experience of implementing mindfulness

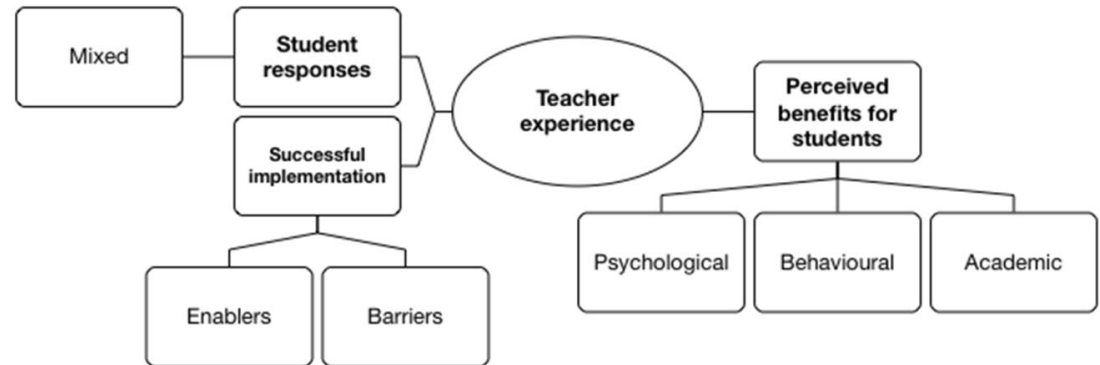


methodological limitations in these studies can also be used to determine whether current MBI research with this age group of students meets the criteria guidelines of effective educational programs in EBP. Finally, the review examined what did and did not work in the papers reviewed to provide educational and practical recommendations for practitioners in the field.

\section{MBls for Early Adolescent School Students}

All papers under review applied an MBI to enhance the wellbeing of early adolescent school-aged students. Emotional wellbeing was the most targeted major intervention outcome. Overall, MBIs for early adolescents appear to be more effective for decreases in negative mental traits (e.g. affective disturbances, anxiety) than increases in positive mental traits (e.g. positive affect, prosocial functioning). Medium to large effect sizes were reported for decreases in negative mental traits, while small effect size was reported for increases in positive mental traits. This would suggest that a MBI program is a suitable wellbeing preventative program to be used with early adolescent school-aged students. The acceptability and feasibility of the programs reported by both the students and teachers provide further additional support for a MBI being a suitable well-being prevention program with this age group of students.

The qualitative analysis containing the voices of students and teachers who participated in the studies under review provides further support for the delivery of MBI programs in schools. For the majority of students, the practice of mindfulness was enjoyable and this allowed them to see a range of benefits including decreases in anger, stress and anxiety and improvements in concentration, behaviour management and sleep quality. These benefits were noticed not only by the students who practised mindfulness but also the teachers who implemented the interventions. However, a minority of students disliked the practice finding it boring, difficult to practise and even exposing sadness and fatigue. Teachers also observed that a small minority of students had difficulties in taking mindfulness activities seriously. These findings highlight important aspects to be noted for successful implementation of MBIs. Mindfulness practice may be beneficial for a majority of early adolescent students, but not necessarily for all. Practising mindfulness may reveal underlying difficult physical and emotional conditions among practitioners, so implementation of MBIs requires the requisite knowledge and skills to deal with unexpected challenges.

\section{Quality Analysis and Evidence-Based Practice}

The use of a quality analysis critique is a useful way to examine the methodological rigour in current studies which can guide future research in this field. In examining the 11 quantitative designed studies (including four mixed-method quantitative focus studies), the main limitations surround the lack of reporting on intervention fidelity, validity measures and measurement of intervention effects at appropriate times. Intervention fidelity is particularly important given the diversity that exists between the programs in content, format and duration. It is also important considering more than one facilitator delivered an MBI program in seven of the 13 studies reviewed. Fidelity of mindfulness interventions can be assessed independently by using a developed checklist (Hwang and Kearney 2015), enabling future studies to be more appropriately compared to one another and ensuring greater confidence in consistency of program delivery to all students in a study.

In examining the two mixed-method (qualitative focus) designed studies, the main limitations surround the lack of reporting on trustworthiness and credibility, a reflexivity statement and the absence of a description of the relationship between researcher and participant. The benefit of employing mixed-method design studies can address some of the limitations that currently surround MBI studies with either a quantitative or qualitative design. Mixed-method design can inform future practices and policies in the field by providing components of both investigation and interpretation. The quality of the methodology in these papers therefore needs to ensure it is rigorous to provide best evidence for MBI research. Whilst the papers examined in this review had a clearly identified quantitative or qualitative focus, it is important that these papers still ensure that they provide appropriate analysis and information on both components of the study. Overall, information on the analysis of both designs was lacking in three of the six mixed-method papers.

These identified limitations are useful for the evaluation of the 13 studies in determining whether they collectively meet criteria required for an intervention in order to be considered as having positive effects within the context of EBP. As a source for EBP in education, the WWC (2017) specified three criteria; (1) statistically significant positive outcomes reported for two or more studies, with effect sizes greater than 0.25 ; (2) at least one of the studies uses randomised controlled trials, showing comparability of participants between intervention and control groups and low attrition; and (3) none of the studies shows statistically significant or considerably important negative effects (Hwang et al. 2017). The current systematic review demonstrates that these three criteria are not yet fully met.

Of the 13 studies reviewed, seven employed randomised trials, reported attrition and established comparability between intervention and control groups (Barnes et al. 2004; Britton et al. 2014; Johnson et al. 2016, 2017; Quach et al. 2016; Sibinga et al. 2013, 2016). Although overall intervention effects were positive, some effect sizes were lower than 0.25 . In addition, two studies (Johnson et al. 2016, 2017) failed to find positive effects and one of them (Johnson et al. 2016) reported 
negative effects as demonstrated by higher anxiety found for males in the intervention group at follow-up. As these two studies were conducted by the same group of researchers, the intervention content and conditions shared by these studies may have contributed to these unexpected findings. For example, both studies relied solely on self-reported measures to evaluate intervention effects, employed the same facilitator to deliver the program and reported lack of practice engagement in students.

Qualitative analysis findings highlighted the importance of ongoing engagement with practice which may indicate a condition conductive to successful delivery of MBIs. Alternatively, these findings may suggest that an MBI may not have positive effects on the well-being of early adolescent school students. This possibility is concerning given the time and resources of implementation. Since other studies reported positive effects of MBIs for the mental and physical well-being of early adolescent students and the students' own experiences support such claims, further investigation is required before drawing any conclusion about whether MBIs meet the criteria of EBP as an effective educational program.

\section{Educational and Practical Considerations}

The other key purpose of this study was to identify the best way to introduce and practise mindfulness with this age group. To fulfil this purpose, it is important to look at what has worked in the studies reviewed. The programs that were delivered to students all varied extensively in content, format, structure and duration. While the core elements of mindfulness, 'present moment awareness' and 'breathing awareness' were highlighted in the majority of the studies, that was where the similarities ended. Only four studies reviewed had curriculum manuals, and one study reported a descriptive approach to the program allowing the teacher to tailor the program to their class. The two studies that reported no positive improvement from pre- to post-test measure were the only two studies in this review to employ the Mindfulness in Schools Project '. b' curriculum. While this program has reported positive effects with older aged adolescent students (Kuyken et al. 2013), the content and format of different mindfulness programs may have varying optimal age ranges for implementation in schools (Johnson et al. 2017). This needs to be investigated in future studies.

The duration of the programs reviewed varied considerably from the number of minutes practised at each session to the frequency of sessions. Positive improvements were reported across programs irrespective of the duration of the lesson or its frequency. This is in line with a recent review of MBIs with adolescents across different settings (Klingbeil et al. 2017), which indicated that intervention dosage may not be nearly as significant as other elements of MBI intervention, such as program facilitators.

The program facilitators in this review were evenly divided between teaching staff and external facilitators. They all had varying degrees of personal practice, training and experience, with external facilitators generally providing more information on their credentials. The only two studies that reported no positive effect were delivered by the same external facilitator (Johnson et al. 2016, 2017). This may indicate that different facilitators will bring their own nuances and personality to the delivery of the program and that this needs to be considered in examining an instructor's suitability for implementing a MBI. In Carsley et al. (2017) review, they reported significant effects on mindfulness post-intervention only in studies with an external facilitator, and significant effects on mental health outcomes post-intervention in studies only with trained teacher facilitators. This again suggests that the facilitator plays an important role in program implementation as they may be more knowledgeable in the material being delivered in some subjects than others. Secondary analysis of qualitative findings stresses student engagement as a key to positive intervention outcomes, which presents a more complicated picture concerning the requirements of facilitators than this single binary approach (i.e. external facilitator vs teacher facilitator).

Teachers nominated student disengagement as a barrier to successful delivery of a MBI. A small group of students found it difficult to engage with practice for a variety of reasons. Of these, difficulties reported by students in dealing with the wandering mind and underlying physical and emotional conditions emphasise the importance of facilitators' knowledge and skills. They need to be equipped with not only the knowledge and skills of teaching mindfulness (e.g. being able to explain that a wandering mind is part of mindfulness practice) but also those of students (e.g. student health and educational backgrounds) in order to adequately address any challenges that can lead to disengagement. In addition, teachers' ability to embody mindfulness was noted as an enabler, along with support from school administrators and parents, a relaxing environment and students' willingness to learn. These findings suggest that it is important to create conditions that are conducive to successful implementation of MBIs.

\section{Limitations and Future Research}

The search strategy employed in this review limited the search with the inclusion criteria of English language and peerreviewed articles only. Therefore, whilst an extensive search was conducted, it is incorrect to claim that the review is exhaustive given the papers excluded that were written in other languages or articles published in other formats (e.g. unpublished theses). The review included all papers that meet the search strategy criteria regardless of the quality of the paper. 
As discussed in the results section of this review, the quality appraisal index that was assigned to each paper varied significantly between the studies. Some papers demonstrated stronger research rigour than others. However, the review included the findings of all of the papers under review to provide a comprehensive picture of MBIs for early adolescents. Interpretation of the systematic review results therefore requires caution.

Despite these limitations, this systematic review presents a synthesis of MBIs that have been delivered specifically to early adolescent school-aged students. Findings of the review demonstrate the potential of MBIs as a tool for enhancing the well-being of early adolescents. They also highlight practical implications for educational professionals who aim to enhance the quality of life of early adolescents through the implementation of MBIs at school. Identified methodological limitations of the existing MBI studies call for future research and this will provide necessary information regarding whether MBIs are an effective educational program for early adolescents within the framework of EBP.

Authors' Contributions PM: designed and executed the study, conducted the search strategy, assisted with data analyses and wrote the paper. Y-SH: collaborated with the design and writing of the manuscript and analysed the quantitative and qualitative data in the review. Both authors established the inclusion/exclusion criteria of the search together, conducted independent quality analysis critiques of each paper and approved the final version of the manuscript for submission.

\section{Compliance with Ethical Standards}

Ethical Approval All procedures performed in studies involving human participants were in accordance with the ethical standards of the institutional and/or national research committee and with the 1964 Helsinki declaration and its later amendments or comparable ethical standards.

Informed Consent For this type of study, formal consent is not required.

Conflict of Interest The authors declare that they have no conflict of interest.

Open Access This article is distributed under the terms of the Creative Commons Attribution 4.0 International License (http:// creativecommons.org/licenses/by/4.0/), which permits unrestricted use, distribution, and reproduction in any medium, provided you give appropriate credit to the original author(s) and the source, provide a link to the Creative Commons license, and indicate if changes were made.

\section{References}

${ }^{1}=$ Studies included in the systematic review.

${ }^{1}$ Arthurson, K. (2015). Teaching mindfulness to year sevens as part of health and personal development. Australian Journal of Teacher Education, 40(5), 27-40.
Atkinson, M., \& Wade, T. (2015). Mindfulness-based prevention for eating disorders: A school-based cluster randomised controlled pilot study. International Journal of Eating Disorders, 48(7), 1024-1037.

${ }^{1}$ Barnes, V., Davis, H., Murzynowski, J., \& Treiber, F. (2004). Impact of meditation on resting and ambulatory blood pressure and heart rate in youth. Psychosomatic medicine, 66(6), 909-914.

Beauchemin, J., Hutchins, T., \& Patterson, F. (2008). Mindfulness meditation may lessen anxiety, promote social skills, and improve academic performance among adolescents with learning disabilities. Complementary Health Practice Review, 13(1), 34-45.

${ }^{1}$ Bernay, R., Graham, E., Devcich, D.A., Rix, G., \& Rubie-Davies, C.M. (2016). Pause, breathe, smile: a mixed methods study of student well-being following participation in an eight-week, locally developed mindfulness program in three New Zealand schools. Advances in School Mental Health Promotion, 9(2), 90-106.

Braun, V., \& Clarke, V. (2006). Using thematic analysis in psychology. Qualitative Research in Psychology, 3(2), 77-101.

${ }^{1}$ Britton, W.B., Lepp, N.E., Niles, H.F., Rocha, T., Fisher, N.E., \& Gold, J.S. (2014). A randomised controlled pilot trial of classroom-based mindfulness meditation compared to an active control condition in sixth- grade children. Journal of School Psychology, 52(3), 263278.

Burke, C. (2010). Mindfulness-based approaches with children and adolescents: A preliminary review of current research in an emergent field. Journal of Child and Family Studies, 19(2), 133-144.

Carsley, D., Khoury, B., \& Heath, N. (2017). Effectiveness of mindfulness interventions for mental health in schools: A comprehensive meta-analysis. Mindfulness. https://doi.org/10.1007/s12671-0170839-2.

${ }^{1}$ Costello, E., \& Lawler, M. (2014). An exploratory study of the effects of mindfulness on perceived levels of stress among school-children from lower socioeconomic backgrounds. International Journal of Emotional Education, 6(2), 21-39.

Creswell, J. W. (2015). Educational research: Planning, conducting, and evaluating quantitative and qualitative research (5th ed.). Boston: Pearson.

Dray, J., Bowman, J., Freund, M., Campbell, E., Wolfenden, L., Hodder, R., \& Wiggers, J. (2014). Improving adolescent mental health and resilience through a resilience-based intervention in schools: study protocol for a randomised controlled trial. Trials, 15(1), 289.

Felver, J. C., Celis-de Hoyos, C., Tezanos, K., \& Singh, N. (2016). A systematic review of mindfulness-based interventions for youth in school settings. Mindfulness, 7(1), 34-45.

Goodwin, K. A., \& Goodwin, C. J. (2016). Research in psychology: Methods and design (8th ed.). New Jersey: Wiley.

Hempenstall, K. (2006). What does evidence-based practice in education mean? Australian Journal of Learning Disabilities, 11(2), 83-92.

Heyvaert, M., Hannes, K., Maes, B., \& Onghena, P. (2013). Critical appraisal of mixed methods studies. Journal of Mixed Methods Research, 7(4), 302-327.

Hwang, Y.S., \& Kearney, P. (2015). A mindfulness intervention for children with autism and spectrum disorders: new directions in research and practice. Springer International Publishing.

Hwang, Y.S., Bartlett, B., Greben, M., \& Hand, K. (2017). A systematic review of mindfulness interventions for in-service teachers: a tool to enhance teacher wellbeing and performance. Teaching and Teacher Education, 64, 26-42.

${ }^{1}$ Johnson, C., Burke, C., Brinkman, S., \& Wade, T. (2016). Effectiveness of a school-based mindfulness program for transdiagnostic prevention in young adolescents. Behaviour Research and Therapy, 81, 111.

${ }^{1}$ Johnson, C., Burke, C., Brinkman, S., \& Wade, T. (2017). A randomised controlled evaluation of a secondary school mindfulness program for early adolescents: Do we have the recipe right yet? Behaviour Research and Therapy, 99, 37-46. 
${ }^{1}$ Joyce, A., Etty-Leal, J., Zazryn, T., Hamilton, A. \& Hassed, C. (2010). Exploring a mindfulness meditation program on the mental health of upper primary children: A pilot study. Advances in School Mental Health Promotion, 3(2), 17-25.

Kabat-Zinn, J. (2003). Mindfulness-based interventions in context: Past, present and future. Clinical Psychology: Science and Practice, 10(2), 144-156.

Klingbeil, D., Renshaw, T., Willenbrink, J., Copek, R., Chan, K., Haddock, A., et al. (2017). Mindfulness-based interventions with youth: A comprehensive meta-analysis of group-design studies. Journal of School Psychology, 63, 77-103.

Kuyken, W., Weare, K., Ukoumunne, O. C., Vicary, R., Motton, N., Burnett, R., et al. (2013). Effectiveness of the mindfulness in schools programme: Non-randomised controlled feasibility study. The British Journal of Psychiatry, 203(2), 126-131.

Lagor, A., Williams, D., Lerner, J., \& McClure, K. (2013). Lessons learned from a mindfulness-based intervention with chronically ill youth. Clinical Practice in Paediatric Psychology, 1(2), 146-158.

Lawrence, D., Johnson, S., Hafekost, J., Boterhoven De Haan, K., Sawyer, M., Ainley, J., \& Zubrick, S.R. (2015). The mental health of children and adolescents. Report on the second Australian child and adolescent survey of mental health and wellbeing. Retrieved on 11 November, 2017 from https://www.health.gov.au/internet/main/publishing.nsf/ Content/9DA8CA21306FE6E DCA257E2700016945/\%24File/ child2.pdf.

McGorry, P. D., Goldstone, S. D., Parker, A. G., Rickwood, D. J., \& Hickie, I. B. (2014). Cultures for mental health care of young people: an Australian blueprint for reform. The Lancet Psychiatry, 1(7), 559-568.

Meiklejohn, J., Phillips, C., Freedman, M. L., Griffin, M. L., Biegel, G., Roach, A., et al. (2012). Integrating mindfulness training into K-12 education: Fostering the resilience of teachers and students. Mindfulness, 3(4), 291-307.

Patel, V., Flisher, A. J., Hetrick, S., \& McGorry, P. (2007). Mental health of young people: a global public- health challenge. The Lancet, 369, 1302-1313.

Patton, G., Sawyer, S., Santelli, J., Ross, D., Afifi, R., Allen, N., et al. (2016). Our future: a Lancet commission on adolescent health and wellbeing. The Lancet, 387(10036), 2423-2478.

Phillips, A., Lewis, L., McEvoy, M., Galipeau, J., Glasziou, P., Moher, D., et al. (2016). Development and validation of the guideline for reporting evidence-based practice educational interventions and teaching (GREET). BMC Medical Education, 16(1), 237.

Pluye, P., Gagnon, M.-P., Griffiths, F., \& Johnson-Lafleur, J. (2009). A scoring system for appraising mixed methods research, and concomitantly appraising qualitative, quantitative and mixed methods primary studies in mixed studies reviews. International Journal of Nursing Studies, 46(4), 529-546.

${ }^{1}$ Quach, D., Jastrowski, K., \& Alexander, K. (2016). A randomised controlled trial examining the effect of mindfulness meditation on working memory capacity in adolescents. Journal of Adolescent Health, 58(5), 489-496.

Sampaio de Carvalho, J., Marques-Pinto, A., \& Marôco, J. (2017). Results of a mindfulness-based social- emotional learning program on Portugese elementary students and teachers: A quasiexperimental study. Mindfulness, 8(2), 337-350.

${ }^{1}$ Schonert-Reichl, K.A., \& Lawlor, M.S. (2010). The effects of a mindfulness-based education program on pre- and early adolescents' well-being and social and emotional competence. Mindfulness, 1(3), 137-151.

Segal, Z. V., Williams, J. M. G., \& Teasdale, J. D. (2002). Mindfulnessbased cognitive therapy for depression: A new approach to preventing relapse. New York: The Guilford Press.

Semple, R. J., Lee, J., \& Miller, L. F. (2006). Mindfulness-based cognitive therapy for children. In R. A. Baer (Ed.), Mindfulness-based treatment approaches: Clinician's guide to evidence base and applications (pp. 143-166). San Diego: Elsevier Academic Press.

Shamseer, L., Moher, D., Clarke, M., Ghersi, D., Liberati, A., Petticrew, M., et al. (2015). Preferred reporting items for systematic review and meta-analysis protocols (PRISMA-P) 2015: elaboration and explanation. $B M J, 349$, g7647.

Shankland, R., \& Rosset, E. (2017). Review of brief school-based positive psychological interventions: a taster for teachers and educators. Educational Psychology Review, 29(2), 363-392.

${ }^{1}$ Sibinga, E., Perry-Parrish, C., Chung, S., Johnson, S., Smith, M., \& Ellen, J.M. (2013). School-based mindfulness instruction for urban male youth: a small randomised controlled trial. Preventive Medicine, 57(6), 799-801.

${ }^{1}$ Sibinga, E., Webb, L., Ghazarian, S.R., \& Ellen, J.M. (2016). Schoolbased mindfulness instruction: An RCT. Paediatrics, 137(1): e20152532.

Singh, N., Lancioni, G., Singh Joy, S., Winton, A., Sabaawi, M., Wahler, R., \& Singh, J. (2007). Adolescents with conduct disorder can be mindful of their aggressive behaviour. Journal of Emotional and Behavioural Disorders, 15(1), 56-63.

Slocum, T. A., Spencer, T. D., \& Detrich, R. (2012). Best available evidence: Three complementary approaches. Education and Treatment of Children, 35(2), 153-181.

Spencer, T. D., Detrich, R., \& Slocum, T. A. (2012). Evidence-based practice: A framework for making effective decisions. Education and Treatment of Children, 35(2), 127-151.

Tan, L. B. (2016). A critical review of adolescent mindfulness-based programmes. Clinical Child Psychology and Psychiatry, 21(2), 193-207.

${ }^{1}$ Viafora, D.P., Mathiesen, S.G., \& Unsworth, S.J. (2015). Teaching mindfulness to middle school students and homeless youth in school classrooms. Journal of Child and Family Studies, 24(5), 1179-1191.

Weare, K. (2013). Developing mindfulness with children and young people: A review of the evidence and policy context. Journal of Children's Services, 8(2), 141-153.

WHO [World Health Organisation] (2017a). Maternal, newborn, child and adolescent health: Adolescent development. Accessed on 28 December, 2017 from http://www.who.int/mental_health/maternalchild/child_adolescent/en/.

WHO [World Health Organisation] (2017b). Adolescents: health risks and solutions. Retrieved on 28 December, 2017 from http://www. who.int/mediacentre/factsheets/fs345/en/.

WWC [What Works Clearinghouse] (2017). What works clearinghouse procedures handbook (Version 4.0). Retrieved on 29 December, 2017 from https://ies.ed.gov/ncee/wwc/Docs/referenceresources/ wwc procedures handbook_v4.pdf.

Zenner, C., Herrnleben-Kurz, S., \& Walach, H. (2014). Mindfulnessbased interventions in schools - a systematic review and meta-analysis. Frontiers in Psychology, 5, 603. 